\title{
HYDROLOGIC EFFECTS OF STORING LIQUIFIED SEWAGE SLUDGE ON STRIP-MINED LAND, FULTON COUNTY, ILLINOIS
}

\author{
G. L. PATTERSON
}

U. S. GEOLOGICAL SURVEY

Water Resources Investigations 82-4047

Prepared in cooperation with the

Metropolitan Sanitary District of Greater Chicago

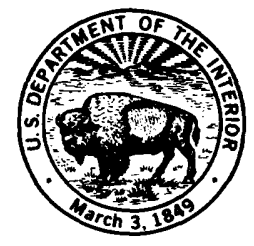

December 1982 


\title{
UNITED STATES DEPARTMENT OF THE INTERIOR
}

\author{
JAMES G. WATT, SECRETARY
}

\section{GEOLOGICAL SURVEY}

Dallas L. Peck, Director

For additional information write to:

\section{U. S. Geological Survey}

Champaign County Bank Plaza

102 East Main, 4th Floor

Urbana, Illinois 61801
Copies of this report

can be purchased from:

Open-File Services Section Western Distribution Branch U.S. Geological Survey Box 25425, Federal Center Lakewood, Colorado 80225 Telephone (303) 234-5888 


\section{CONTENTS}

Page

Abstract $\ldots \ldots \ldots \ldots \ldots \ldots \ldots \ldots \ldots \ldots \ldots \ldots \ldots \ldots \ldots \ldots \ldots \ldots \ldots \ldots \ldots \ldots$

Introduction $\ldots \ldots \ldots \ldots \ldots \ldots \ldots \ldots \ldots \ldots \ldots \ldots \ldots \ldots \ldots \ldots \ldots \ldots \ldots \ldots$

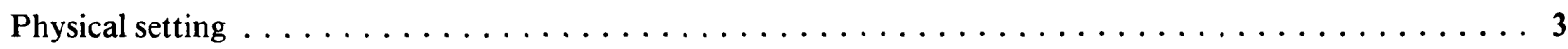

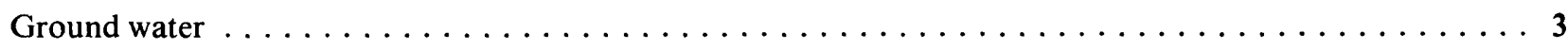

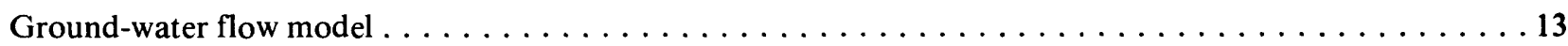

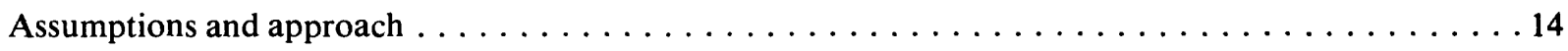

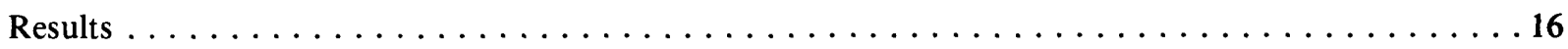

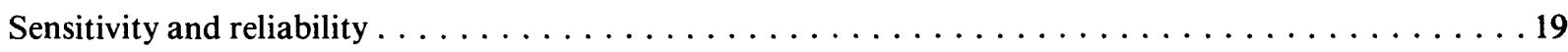

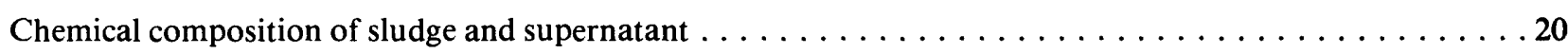

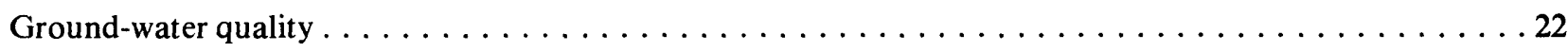

Relation of ground-water quality to basin contents $\ldots \ldots \ldots \ldots \ldots \ldots \ldots \ldots \ldots \ldots \ldots \ldots \ldots \ldots \ldots \ldots$

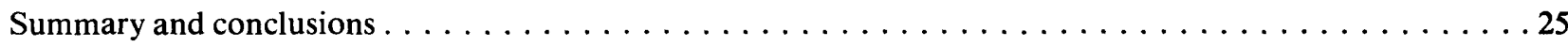

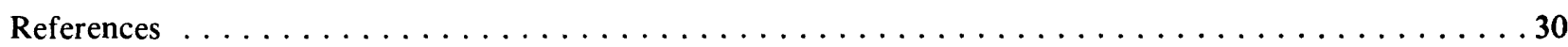

\section{ILLUSTRATIONS}

Page

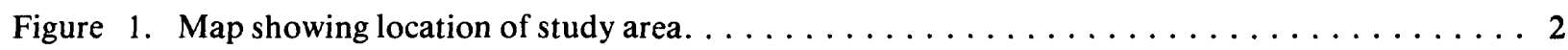

2. Map showing location of data collection sites and cross sections $\ldots \ldots \ldots \ldots \ldots \ldots$

3. Map showing altitude of bottom surface of basins and adjacent

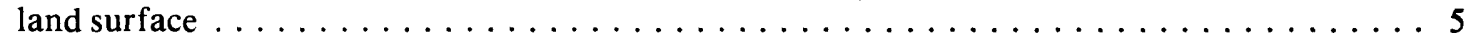

4. Cross section through sludge-storage basins, showing pre-construction and post-construction (June 1979) water table $\ldots \ldots \ldots \ldots \ldots \ldots \ldots \ldots \ldots \ldots$

5. Map showing approximate water table before basin construction $\ldots \ldots \ldots \ldots \ldots \ldots$

6. Map showing water table after basin construction (June 1979) $\ldots \ldots \ldots \ldots \ldots \ldots$

7. Hydrographs showing (A) Liquid levels in four storage basins;

(B) Precipitation; (C) Ground-water levels in 10 wells . . . . . . . . . . . . . 11

8. Hydrographs showing ground-water levels in wells clustered in

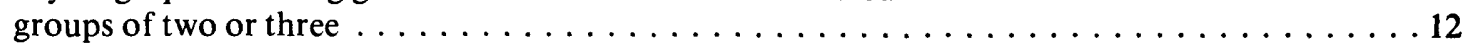

9. Map showing ground-water flow model boundaries $\ldots \ldots \ldots \ldots \ldots \ldots \ldots \ldots$

10. Map showing water table before basin construction,

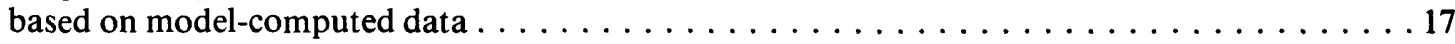

11. Map showing water table in June 1979 , based on

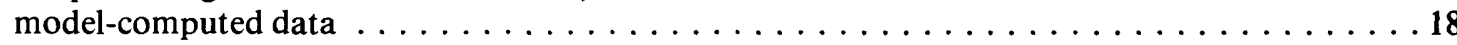


Table 1. Grain size, clay mineralogy, and cation exchange capacity of mine spoil samples $\ldots \ldots \ldots \ldots \ldots \ldots \ldots \ldots \ldots \ldots \ldots \ldots$

2. Wells clustered in groups of 2 or 3 and the altitudes and depths of their screened intervals . . . . . . . . . . . . . . . . . . . . . . . 10

3. Hydraulic conductivities of strip-mine spoil as determined

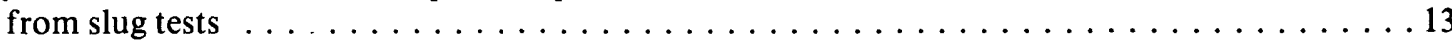

4. Results of sensitivity analyses of major parameters used in the ground-water flow model . . . . . . . . . . . . . . . . . . . . 20

5. Summary of chemical analyses of unfiltered sludge samples

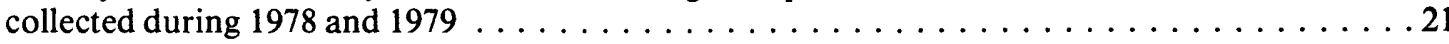

6. Chemical analyses of centrifuged sludge and supernatant . . . . . . . . . . 23

7. Summary of chemical analyses of settled, unfiltered water

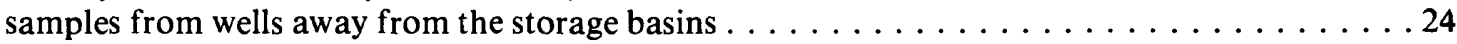

8. Concentration, in milliequivalents per liter, and percent reacting values of the principal cations and anions in settled, unfiltered samples

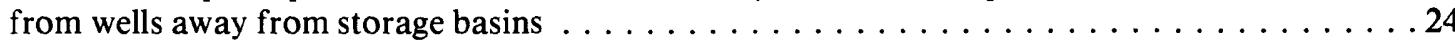

9. Summary of chemical analyses of filtered samples from wells near the storage basins.

10. Concentration, in milliequivalents per liter, and percent reacting values of the principal cations and anions in settled, unfiltered water samples from wells near the storage basins

\section{FACTORS FOR CONVERTING INCH-POUND UNITS TO INTERNATIONAL SYSTEM (SI) UNITS}

Multiply

inch (in)

foot (ft)

yard (yd)

mile (mi)

acre

cubic yard $\left(\mathrm{yd}^{3}\right)$

cubic yard per year $\left(\mathrm{yd}^{3} / \mathrm{yr}\right)$

foot per second $(\mathrm{ft} / \mathrm{s})$

inch per year (in/yr)

cubic foot per second $\left(\mathrm{ft}^{3} / \mathrm{s}\right)$

mho
By

25.4

0.3048

0.9144

1.609

0.4047

0.7645

0.7645

0.3048

25.4

0.02832

1.0
To obtain SI unit

millimeter (mm)

meter (m)

meter (m)

kilometer (km)

hectare (ha)

cubic meter $\left(\mathrm{m}^{3}\right)$

cubic meter per year $\left(\mathrm{m}^{3} / \mathrm{yr}\right)$

meter per second $(\mathrm{m} / \mathrm{s})$

millimeter per year $(\mathrm{mm} / \mathrm{yr})$

cubic meter per second $\left(\mathrm{m}^{3} / \mathrm{s}\right)$

siemen

National Geodetic Datum of 1929 (NGVD of 1929): A geodetic datum derived from a general adjustment of the first-order level nets of both the United States and Canada, formerly called "Mean Sea Level". NGVD of 1929 is referred to as sea level in this report. 


\title{
HYDROLOGIC EFFECTS OF STORING LIQUIFIED SEWAGE SLUDGE ON STRIP-MINED LAND, FULTON COUNTY, ILLINOIS
}

\author{
G. L. PATTERSON
}

\begin{abstract}
The water table near four sewage sludge storage basins in a strip-mined area of western Illinois, has risen about 10 feet since the basins were constructed in 1971. Two-dimensional modeling of groundwater flow in the mine spoil indicates that the rise is caused by leakage from storage basin 1 . The hydrologic-parameter values producing the best fit between computed and observed head values are 7 $\times 10^{-6}$ feet per second for the hydraulic conductivity of the mine spoil, $4 \times 10^{-9}$ feet per second $(1.51$ inches per year) for the areal recharge rate, and 5.6 $\times 10^{-8}$ feet per second (21.1 inches per year) for recharge from basin 1 . The model indicates that the volume of water leaking from basin 1 is 91,600 cubic yards per year.

The principal components of the sewage sludge after the solids have been removed are alkalinity, nitrogen, phosphorus, and chloride. In ground water away from the storage basins, the principal cation was magnesium, whereas in that near the basins, the principal cation was sodium. Components in higher concentrations near the basins were sodium, alkalinity, and chloride. Sulfate was the principal anion in both areas. Because the sodium and chloride concentrations in the sludge were too low to cause the higher concentrations in the ground water, the strip-mine spoil used in constructing the basins was considered to be the major source of these constituents. This spoil had been moved from its original location and unweathered surfaces exposed, which allowed dissolution of carbonate and chloride and release of sodium through cation exchange.
\end{abstract}

\section{INTRODUCTION}

The Metropolitan Sanitary District of Greater Chicago (MSDGC) has been operating a sewage sludge disposal and surface-mine reclamation project in Fulton County, Illinois, since 1971. The MSDGC project, about 25 miles west of Peoria (fig. 1), consists of 15,527 acres of land that was surface-mined for coal from the 1920's to the early 1960 's, before enactment of reclamation laws.

The term "sludge", as used in this report, refers to a fluid mixture, resulting from sewage treatment, that contains about 5 percent solid matter. The sludge is barged about $\mathbf{2 0 0}$ miles down the Illinois River from Chicago to Liverpool (fig. 1), and pumped through 10 miles of pipeline to four sludge storage basins. From the storage basins, the sludge is pumped to the fields by a piped distribution system and incorporated directly into the topsoil, where it serves as a soil conditioner and as a fertilizer. During storage at the project site, the solid matter settles to the bottom; the solution left at the top is referred to herein as "supernatant". Supernatant is applied to the fields as an irrigant and fertilizer.

In 1971, the U.S. Geological Survey (USGS) began a cooperative study to measure stream discharge, suspended-sediment load, and chemical quality of surface waters draining the project area. In 1976, the study was expanded to include measurement of ground-water levels and quality. The general hydrologic system in the vicinity has been described by Patterson, Fuentes, and Toler (1982). 


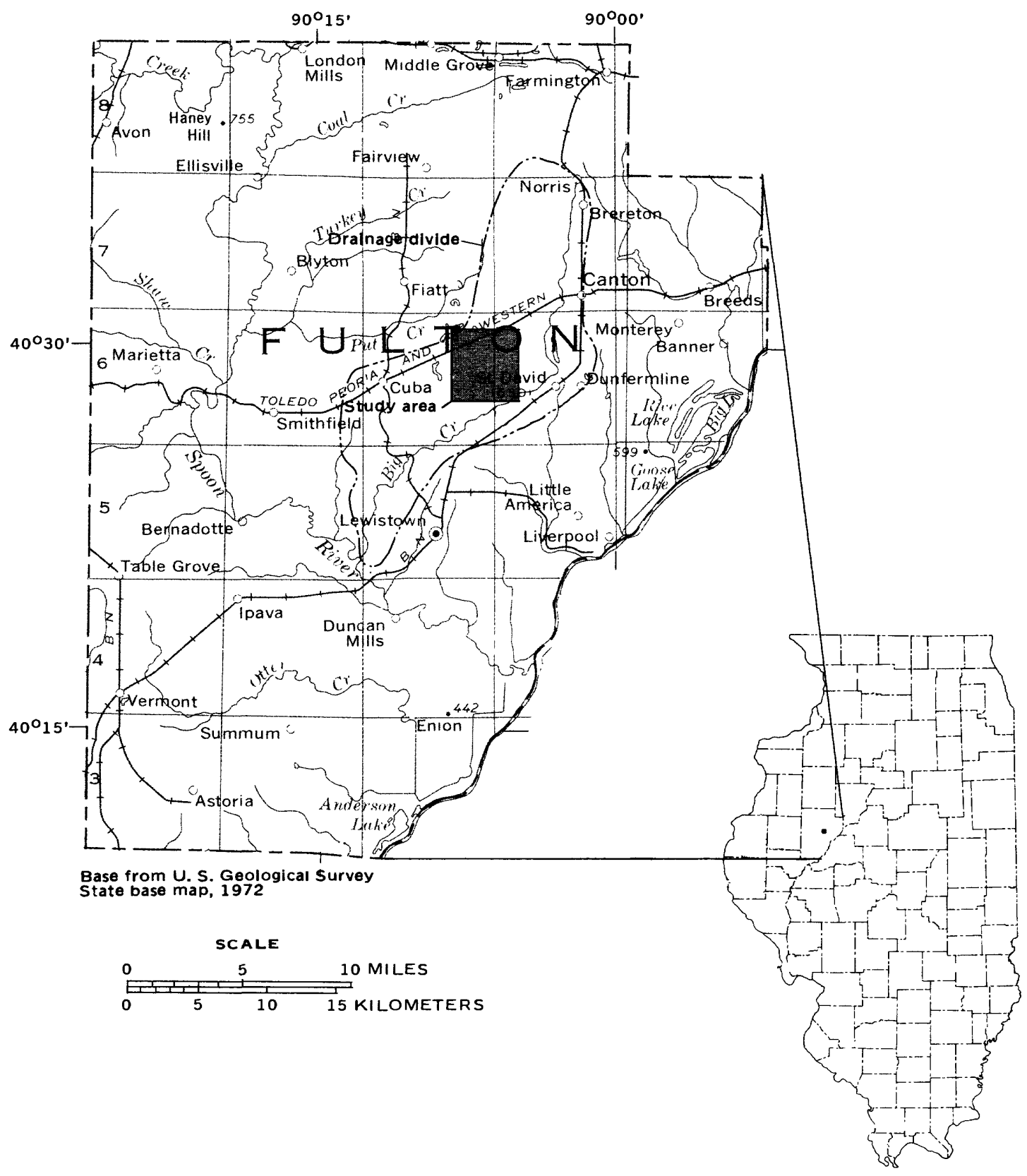

Figure 1. Location of study area. 
Although sewage sludge contains beneficial plant nutrients, such as phosphorus and nitrogen and organic soil conditioners, it can also contain potentially toxic constituents, such as cadmium, lead, and other metals. Because of this potentially toxic composition, and a large difference in liquid level between the sludge storage basins and the shallow water table, a study was begun in 1978 to determine in detail the hydraulic and water-quality relation of the four basins to the ground-water system. This study included measurements of water levels and ground-water quality near the basins and the use of a two-dimensional ground-water flow model to investigate leakage from the basins.

\section{PHYSICAL SETTING}

Bedrock in the area before mining consisted of alternating horizontal layers of coal, limestone, shale, and sandstone of the Carbondale Formation of the Pennsylvanian System. Overlying the bedrock were glacial drift and loess. During mining, all material overlying the coal (predominantly shale and loess) was stripped, mixed, and redeposited, leaving an unsorted, uncompacted mixture of clay, silt, and sand containing many large fragments of bedrock.

The sludge-storage basins were constructed on partly reclaimed land which had been recontoured from an irregular post-mining surface to a gently sloping surface. Dominant surface features include several interconnected surface-mine lakes and a prominent drainage ditch, which drains into Evelyn Branch (figs. 1 and 2), a tributary to Big Creek (fig. 1).

The numbering sequence and bottom configuration of the storage basins are shown in figures 2 and 3. Basins 1 and 2 store sludge pumped from Liverpool. Basins $3 \mathrm{a}$ and $3 \mathrm{~b}$ store supernatant, the liquid removed from the upper parts of basins 1 and 2 after solids have settled to the bottom. Basin 1 , completed in July 1971, has a maximum depth of 45 feet, a bottom altitude of 625 feet (all altitudes are referenced to sea level), and a storage capacity of roughly 2 million cubic yards. Basin 2, completed in January 1972, is 40 feet deep, has a bottom altitude of 653 feet, and a storage capacity of 3 million cubic yards. Basins $3 \mathrm{a}$ and $3 \mathrm{~b}$, completed in August 1972, are about 35 feet deep, have bottom altitudes of 647 and 640 feet, respectively, and have a combined storage capacity of 3 million cubic yards. Each basin was lined with a 2-foot layer of compacted clay-rich mine spoil to minimize leakage. Sections showing elevations of basins and water levels are presented in figure 4.

In October 1978, the USGS installed 18 wells (fig. 1) for monitoring water levels and collecting water samples. Mine-spoil samples were collected by split-spoon and shelby-tube methods, and 18 samples were analyzed for grain-size distribution, clay mineralogy, and cation exchange capacity (table 1). Grain-size analyses show that the matrix of most samples, excluding large shale or limestone fragments, was over 90 percent silt-size plus claysize. Clay mineral content and cation exchange capacities indicate a high compositional variability in the mine spoil, both areally and with depth. Cation exchange capacities ranged from 16 to 77 milliequivalents per 100 grams of air-dried sample and show no correlations or trends between wells or within individual wells.

\section{GROUND WATER}

The configuration of the water table before construction of the storage basins was estimated from MSDGC test boring data and pond and lake levels from a 1969 topographic map. Water-table contours (fig. 5) indicate that in 1969 ground water flowed west to east, fanned outward through the present basin site, and discharged into the surface drainage system. The altitude of the water table ranged from about 660 feet in the western part of the area to about 580 feet near Evelyn Branch. Directly under the present basin site, the water-table altitude ranged from 650 to 610 feet.

The water-table altitude at the location of basin 1 , before basin construction, ranged from 640 to 620 feet. The deepest part of basin 1 is at an altitude of 625 feet, indicating that the basin bottom was constructed below the water table. The bottoms of basins $2,3 \mathrm{a}$, and $3 \mathrm{~b}$ were constructed at or above the water table.

Data collected during June 1979, from 18 wells and 7 piezometers adjacent to the storage basins, were used to prepare a water-table map (fig. 6) representing ground-water conditions after several years of basin operation. Liquid levels in the basins (fig. 7) had been constant for several months before June, therefore near steady state hydraulic conditions could be assumed between the nearby ground 


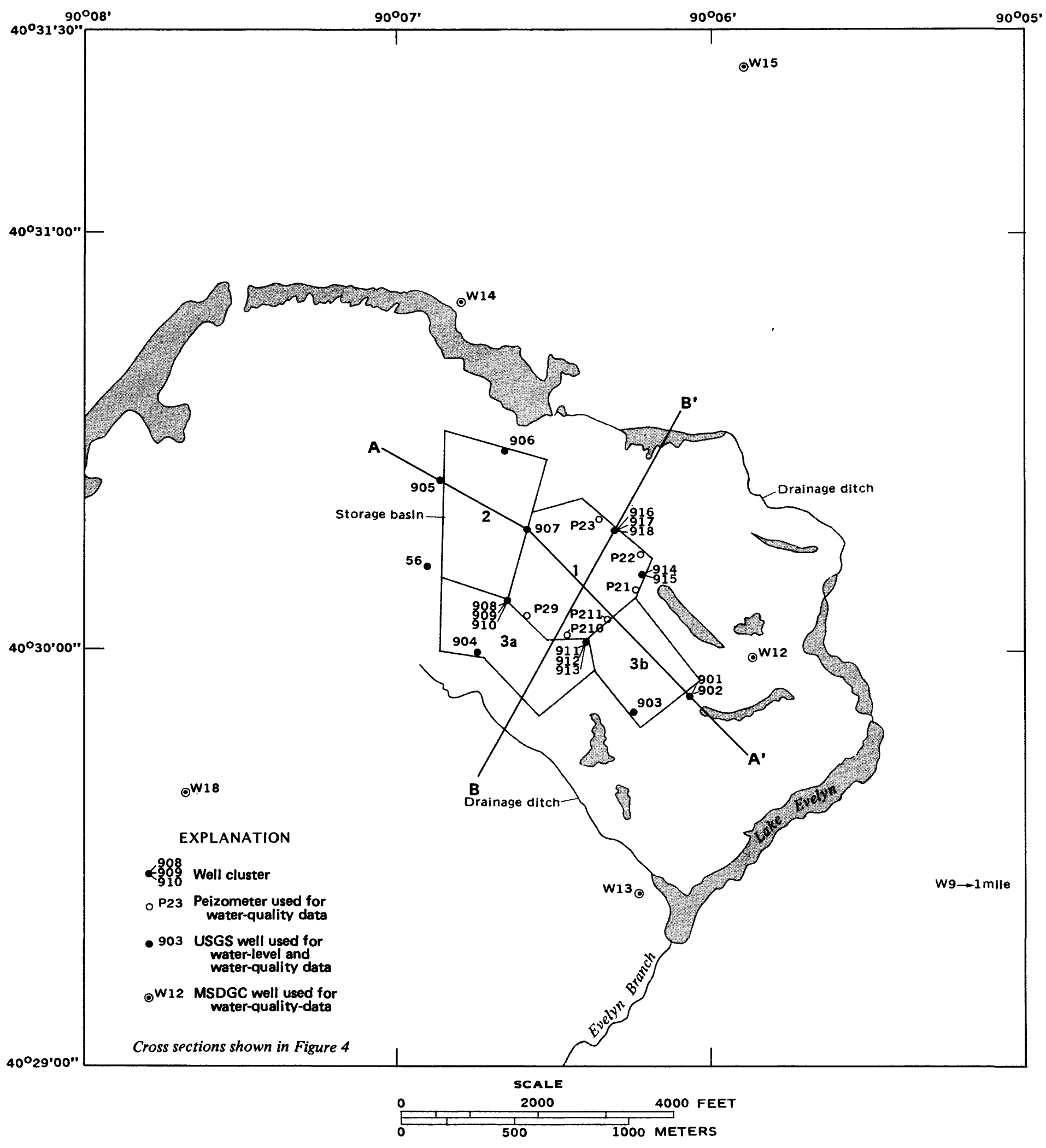

Figure 2. Location of data collection sites and cross sections. 


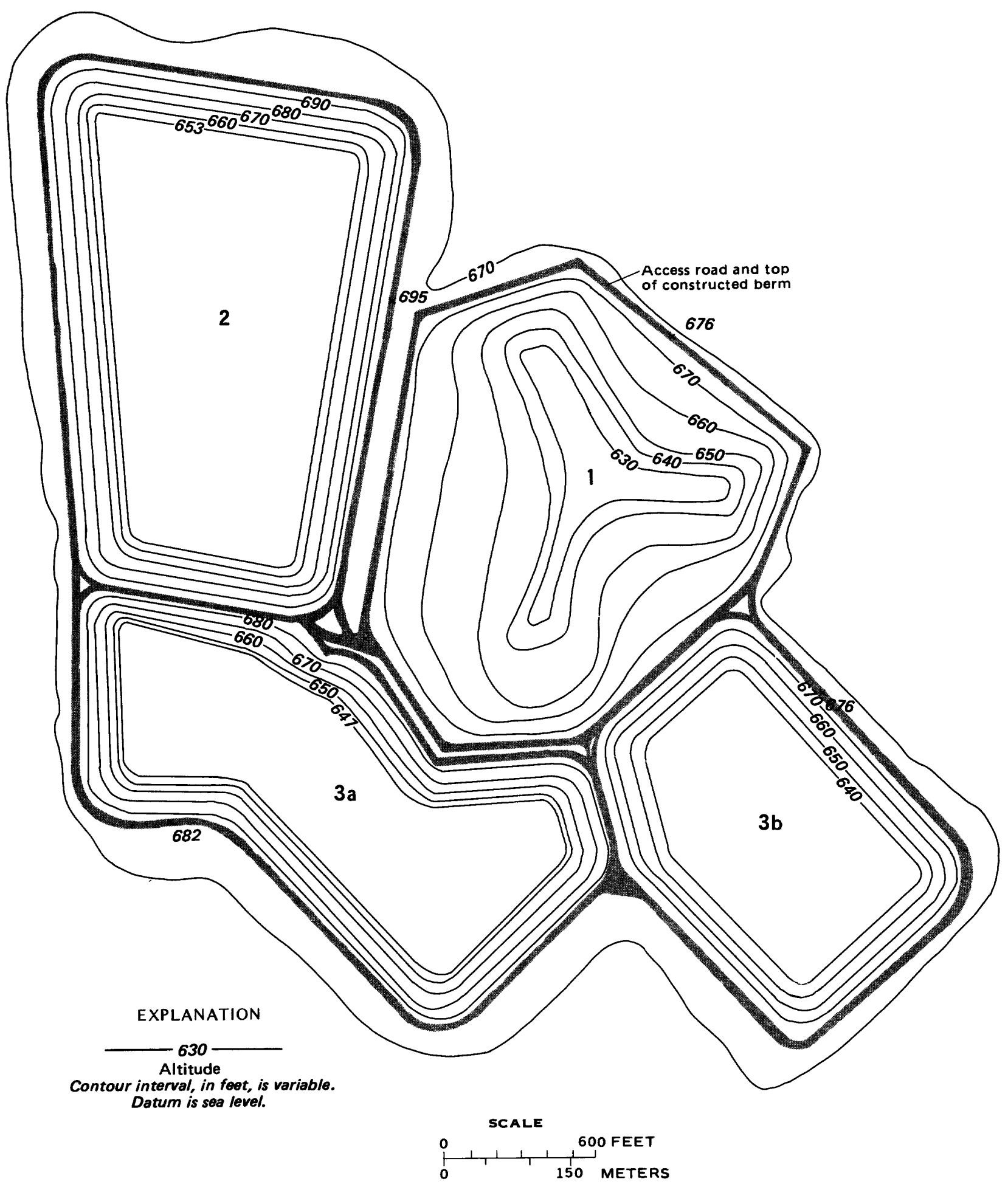

Figure 3. Altitude of bottom surface of basins and adjacent land surface. 


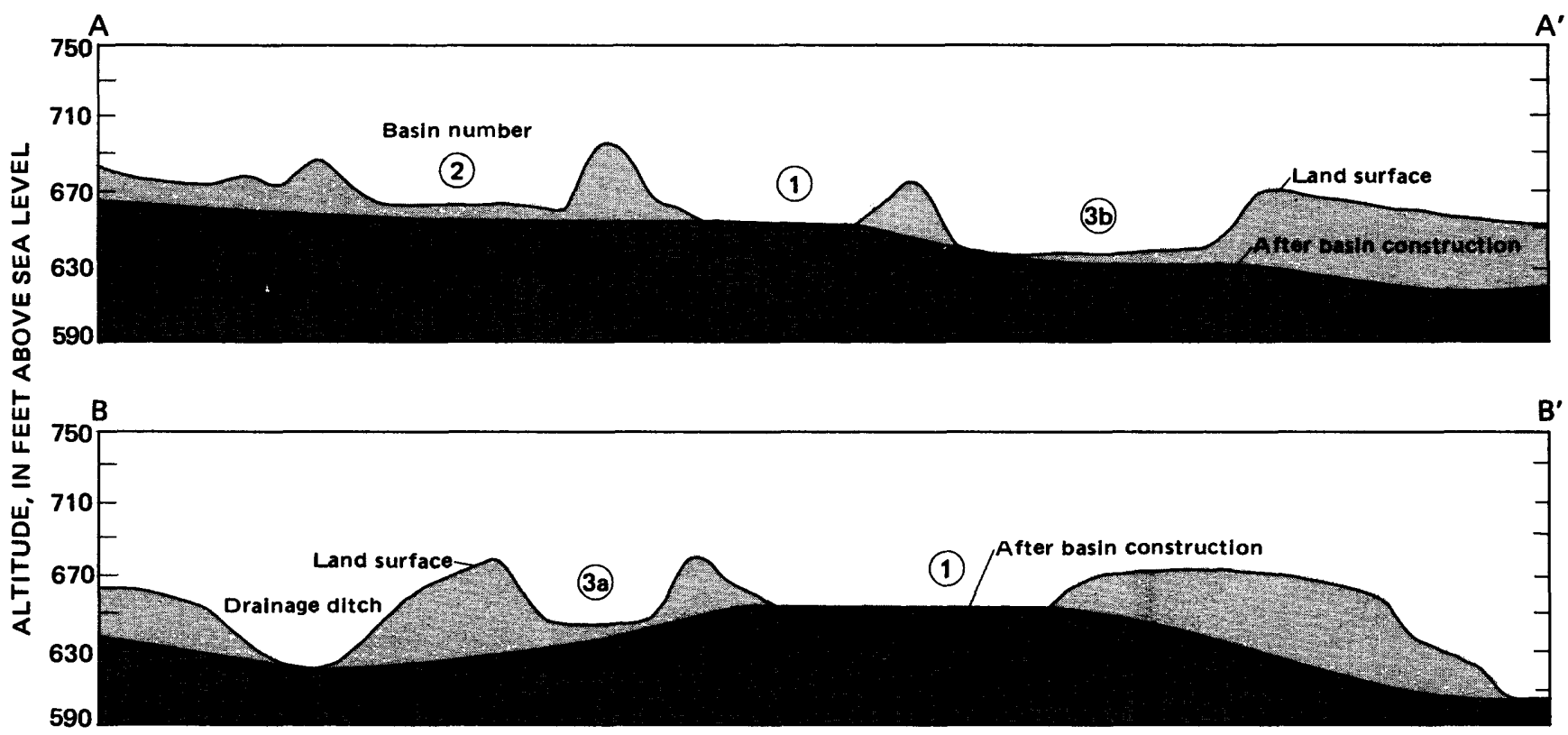

See Figure 2 for cross-section locations.

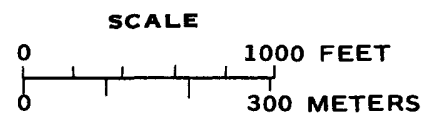

Figure 4. Cross sections through storage basins showing pre-construction and post-construction (June 1979) water table.

water and the basins. Comparison between the 1969 water table (fig. 5) and the 1979 water table (fig. 6) shows that changes have occurred since basin construction. The June 1979 data reflect greater increases in water levels near basins 1 and 2 than in the remainder of the site. Since basin construction, the water table has risen to between 20 and 25 feet above the bottom of basin 1 , but has remained slightly below the bottoms of basins $2,3 a$, and $3 b$.

Hydrographs of liquid levels in the storage basins (fig. 7) show nearly constant levels from January 1979 to May 1979. In May, sludge and supernatant were removed from basins 1 and $3 a$ for application to fields. In July 1979, sludge was pumped from basin 2 into basin 1, and supernatant was pumped from basin $3 \mathrm{~b}$ into basin 3a. By October 1979, liquid levels had reached their lowest, and no additional pumpage into or out of the basins had occurred as of May 1980. The slight increases in liquid levels in the spring of 1980 were due to precipitation.
Hydrographs of monthly water levels for 10 wells and of precipitation (fig. 7) show a rise in water levels, in response to precipitation during the spring of 1979 , followed by a steady decline during the remainder of the year. Some wells show slight water-level rises in May 1980 in response to spring rainfall; however, the rises are much smaller than those in 1979 and are in response to nearly the same amount of total precipitation. The difference in response of the water table to precipitation may be due to less recharge from the basins and to variations in the distribution of precipitation. If the basins and ground-water system were hydraulically connected, lowering liquid levels in the basins would lower the head gradient and decrease recharge from the basins to the ground-water system. Although the relative lack of a spring 1980 water-level rise may be due in part to decreased recharge from the basins, it does not by itself provide conclusive evidence of hydraulic connection. 


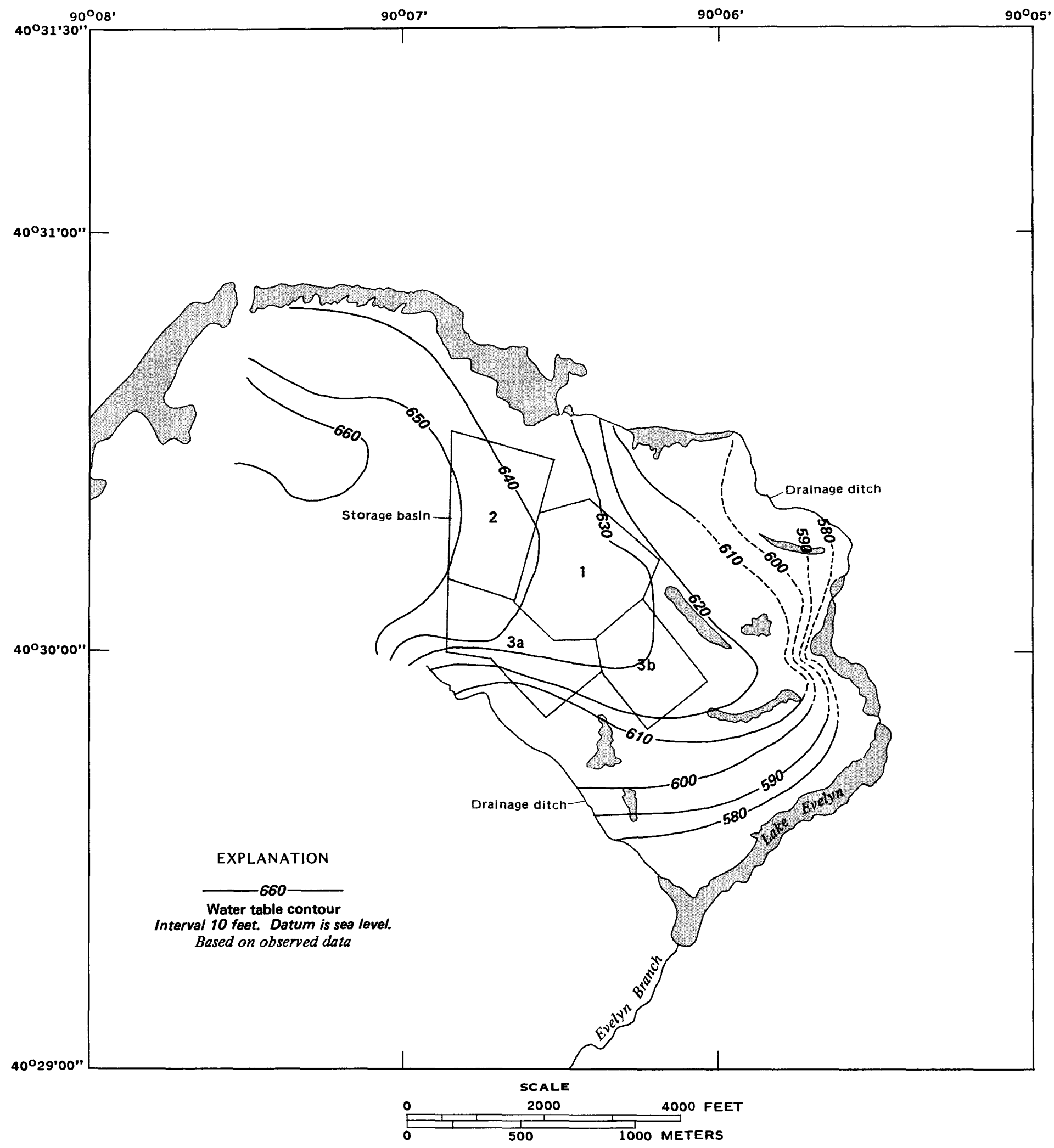

Figure 5. Approximate water table before basin construction. 


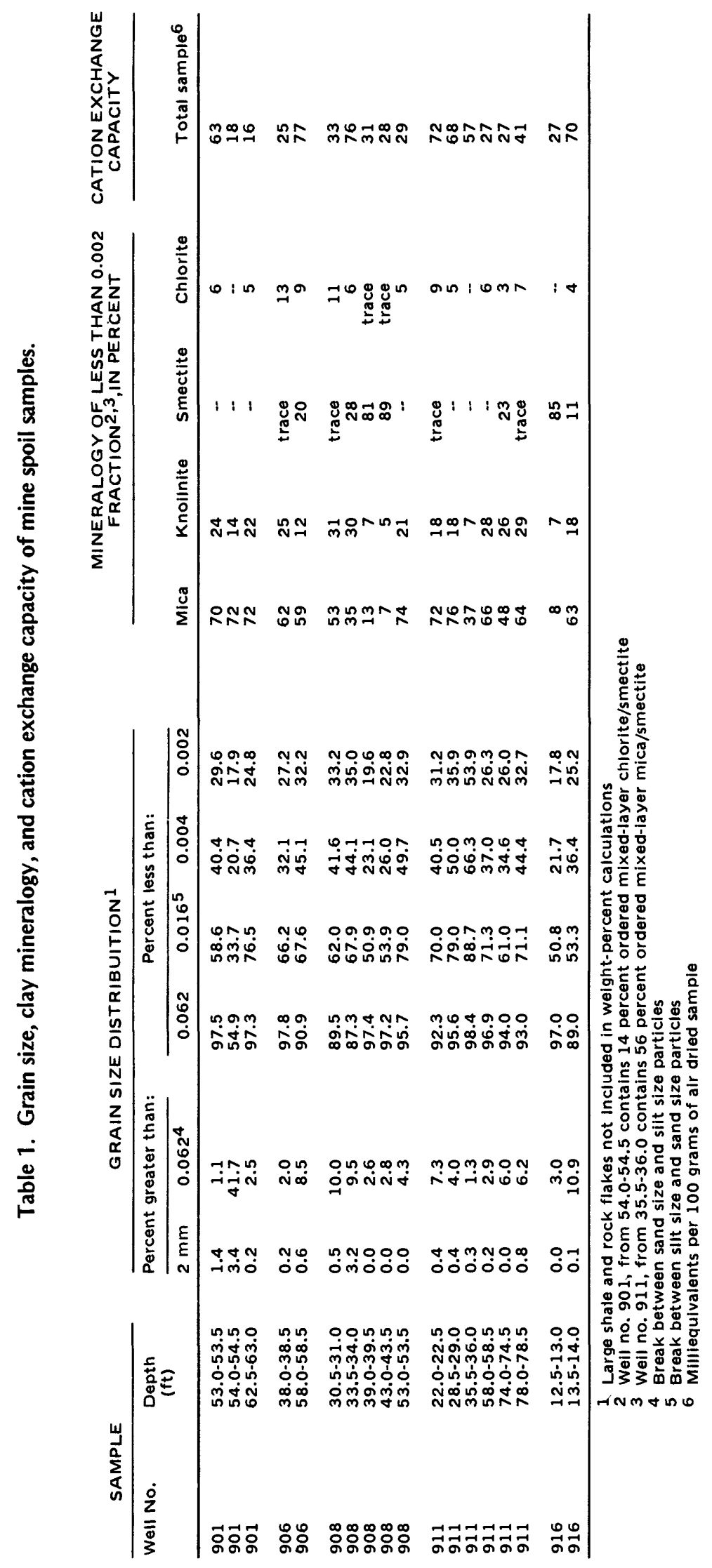




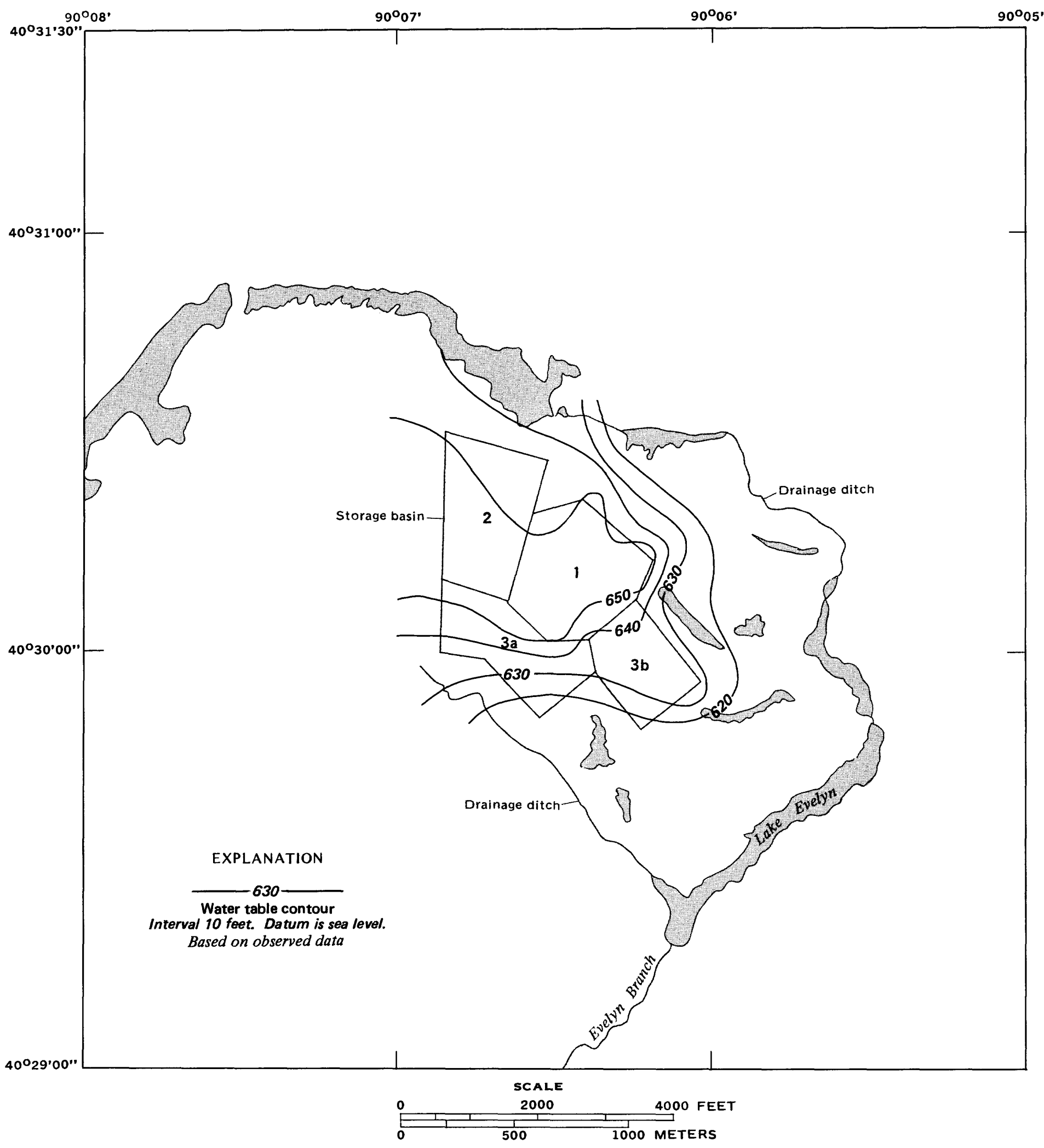

Figure 6. Water table after basin construction, June 1979. 
Thirteen of the wells were clustered in groups of two or three and screened at different depths (table 2) to determine vertical head variation. Head differences between wells in each cluster were generally less than 1 foot but as much as 3 feet (fig. 8). Variations in head within and between clusters indicate complex hydrologic conditions in the mine spoil. Wells in the 911-912-913 cluster show no significant vertical gradient, indicating essentially horizontal flow. Well clusters 901-902 and 914-915 show inconsistent periodic reversals in gradient. Well clusters 908-909-910 and 916-917-918 also show several gradient reversals; however, the head in the well screened at intermediate depth is commonly above or below the head in both of the other wells in the cluster. These seemingly random variations are probably reflections of the lag time produced by different hydraulic conductivities of different zones in the mine spoil.
Hydraulic conductivities of the mine spoil were determined by using a slug test method described by Bouwer and Rice (1976). This method was chosen because of its applicability to partially penetrating wells in unconfined aquifers. A volume or slug of water was instantaneously removed from the well with a 3-foot by 3-inch bailer. Water-level recovery was measured every 10 or 15 seconds for the first 10 minutes and every minute afterward until recovery was nearly complete.

Hydraulic conductivities calculated from slug tests (table 3 ) were highly variable, indicating again the variability of the mine spoil. The values range from $4.4 \times 10^{-7}$ to $2.1 \times 10^{-5} \mathrm{ft} / \mathrm{s}$, the mean value being $7 \times 10^{-6} \mathrm{ft} / \mathrm{s}$.

Table 2. Wells clustered in groups of 2 or 3 and the altitudes and depths of their screened intervals.

We 11 No.

901

902

908

909

910

911

912

913

914

915

916

917

918

\author{
Altitude of \\ screened interval \\ (feet)
}

\author{
Depth of \\ screened interval \\ (feet)
}

$$
\begin{aligned}
& 59.51-62.51 \\
& 51.51-54.51 \\
& 59.22-62.22 \\
& 46.70-49.70 \\
& 37.20-40.20 \\
& 77.80-80.80 \\
& 64.02-67.02 \\
& 54.42-57.42 \\
& 67.25-70.25 \\
& 35.90-38.90 \\
& 66.87-69.87 \\
& 56.50-59.50 \\
& 30.60-33.60
\end{aligned}
$$




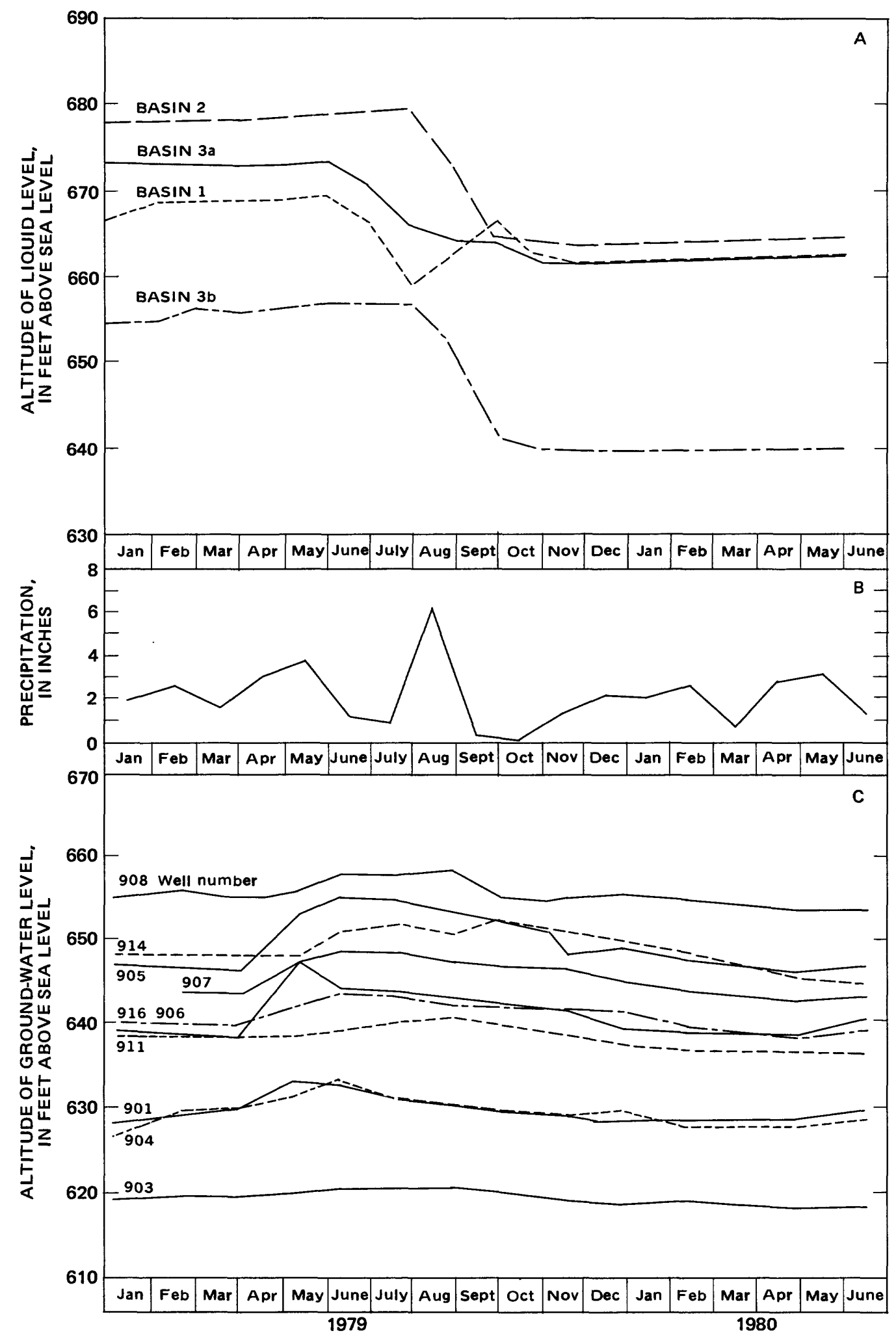

Figure 7. (A) Liquid levels in four storage basins; (B)Precipitation; (C) Ground-water levels in 10 wells. 


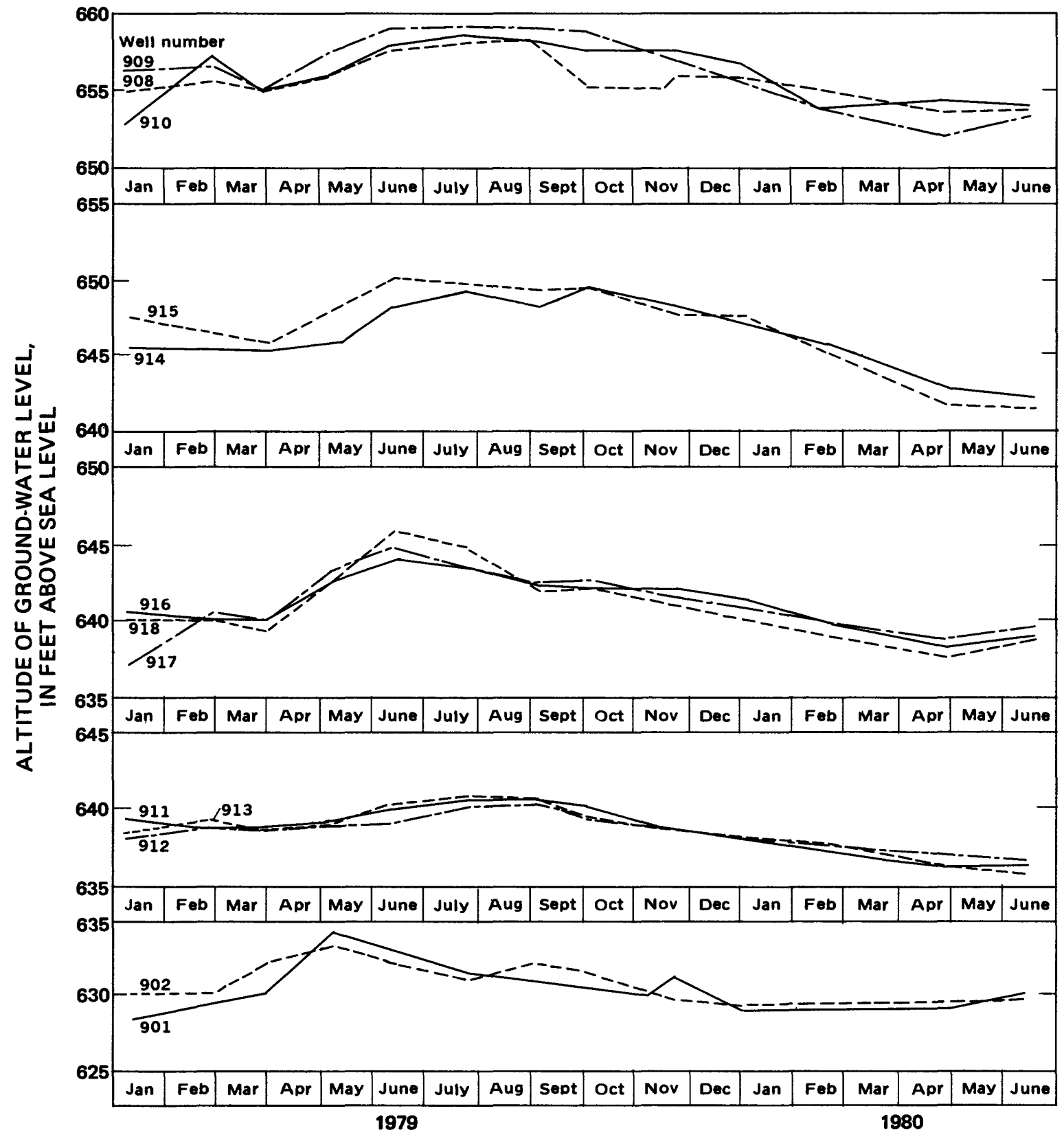

Figure 8. Ground-water levels in wells clustered in groups of two or three. 
Table 3. Hydraulic conductivities of strip-mine spoil as determined from slug tests.

We 11 No.

901

902

903

905

907

909

911

914

915

916
Hydraulic

Conductivity

$2.1 \times 10^{-5} \mathrm{ft} / \mathrm{s}$

$5.0 \times 10^{-6} \mathrm{ft} / \mathrm{s}$

$1.1 \times 10^{-5} \mathrm{ft} / \mathrm{s}$

$4.4 \times 10^{-7} \mathrm{ft} / \mathrm{s}$

$4.9 \times 10-7 \mathrm{ft} / \mathrm{s}$

$1.0 \times 10^{-5} \mathrm{ft} / \mathrm{s}$

$4.8 \times 10^{-6} \mathrm{ft} / \mathrm{s}$

$6.7 \times 10^{-6} \mathrm{ft} / \mathrm{s}$

$3.6 \times 10^{-6} \mathrm{ft} / \mathrm{s}$

$6.5 \times 10^{-6} \mathrm{ft} / \mathrm{s}$

Mean

$7.0 \times 10^{-6} \mathrm{ft} / \mathrm{s}$

Standard deviation

$5.72 \times 10^{-6} \mathrm{ft} / \mathrm{s}$

\section{GROUND-WATER FLOW MODEL}

A two-dimensional ground-water flow model was used to help determine the cause of changes in ground-water levels between 1969 and 1979 (figs. 5 and 6) and to estimate the rate of leakage from the storage basins. The modeling technique was that of Trescott, Pinder, and Larson (1976).
The basic flow equation in water-table aquifers may be expressed as:

$\frac{\delta}{\delta \mathrm{x}}\left(\mathrm{K}_{\mathrm{xx}} \mathrm{b} \frac{\delta \mathrm{h}}{\delta \mathrm{x}}\right)+\frac{\delta}{\delta \mathrm{y}}\left(\mathrm{K}_{\mathrm{yy}} \mathrm{b} \frac{\delta \mathrm{h}}{\delta \mathrm{y}}\right)=\mathrm{S}_{\mathrm{y}} \frac{\delta \mathrm{h}}{\delta \mathrm{t}}+\mathrm{W}(\mathrm{x}, \mathrm{y}, \mathrm{t})$ 
in which

$h$ is the hydraulic head $(L)$,

$\mathrm{K}_{\mathrm{xx}}, \mathrm{K}_{\mathrm{yy}}$ are the principal components of the hydraulic conductivity tensor $\left(\mathrm{LT}^{-1}\right)$,

$S_{y}$ is the specific yield of the aquifer (dimensionless),

b is the saturated thickness of the aquifer $(\mathrm{L})$,

$W(x, y, t)$ is the volumetric flux of recharge or withdrawal per unit surface area of the aquifer $\left(\mathrm{LT}^{-1}\right)$.

The area to be modeled is subdivided graphically into rectangular blocks for which the aquifer properties are assumed to be uniform. Continuous derivatives in the equation are replaced by finite difference approximations of the derivatives at a point or node at the center of the block. The result is $\mathbf{N}$ simultaneous equations with $\mathrm{N}$ unknowns (head values at the nodes) where $\mathrm{N}$ is the number of blocks representing the aquifer.

\section{Assumptions and Approach}

To simulate hydrologic conditions, the mine spoil was assumed to be isotropic, and the water table was assumed to be at steady state in 1969 and in 1979. Isotropic conditions mean that the hydraulic conductivity at a point is equal in all directions. Hence in equation $1 \mathrm{~K}_{\mathrm{xx}}$ and $\mathrm{K}_{\mathrm{yy}}$ equal $\mathrm{K}$, the hydraulic conductivity of the mine spoil. Steadystate conditions mean that water levels do not change with time, which makes equation 1 equal to 0 . Therefore, the actual equation solved in the model is:

$$
\mathrm{Kb} \frac{\delta^{2} \mathrm{~h}}{\delta \mathrm{x}^{2}}+\mathrm{Kb} \frac{\delta^{2} \mathrm{~h}}{\delta \mathrm{y}^{2}} \cdot \mathrm{W}=0
$$

where $\mathrm{W}$ is the total recharge per unit surface area of the aquifer. The assumption was also made that the change in water-table altitude between 1969 and 1979 was caused by leakage from the basins.

The modeling approach used was first to simulate the pre-basin water table (fig. 5) and then superimpose potential effects of leakage from the basins by using different recharge rates at nodes representing the basins. A 200-by-200 foot grid spacing was used to represent the modeled area $\left(1.68 \mathrm{mi}^{2}\right)$. The modeled area is bounded by a ground-water divide to the west, a deep drainage ditch to the south, and a series of interconnected strip-mine lakes to the north and east (fig. 9). The lakes and ditch are continuous with the water table, and their surface altitudes are regulated by outlet pipes, weirs, and earth dams. These boundaries are treated in the model as constant head boundaries. The western boundary, located approximately along a ground-water divide, is treated as a no-flow boundary.

Calculated values of hydraulic conductivity (table 3) vary substantially over the site. However, these values represent only the material present at the screened interval, and core samples have shown widespread random heterogeneity within the spoil. Hence, no attempt was made to delineate zones of uniform hydraulic conductivity. Instead, the arithmetic mean of all values, $7.0 \times 10^{-6} \mathrm{ft} / \mathrm{s}$, was used for the entire study area.

The bottom altitude of the mine spoil, used in calculating saturated thickness (b), is based on test-hole logs and mining records and ranges from 550 to 558 feet.

Of the four variables needed to solve equation 2 , data were available for hydraulic conductivity $(\mathrm{K})$, saturated thickness (b), and hydraulic head (h). After assigning the known values of hydraulic conductivity and saturated thickness, areal recharge (W), the unknown variable, was adjusted until contours of the computed head values best matched contours on the pre-basin water-table map (fig. 5). For this step of the model, the best match was determined by visually comparing the contour maps.

Recharge values for nodes in the model that represented basins were then superimposed on the pre-basin model to simulate leakage from the basins. Data obtained in June 1979 were used in determining the best fit because liquid levels in the holding basins had been nearly constant for several months, and the nearby ground-water flow was most likely to have been near steady-state at that time with respect to the basins.

The best fit for this simulation was determined to be that resulting from use of the set of parameters that minimized the error function $E\left(h_{i}, h_{i}\right)$, where:

$$
E=\sqrt{\sum_{i=1}^{J} \frac{\left(h_{i}-h_{i}\right)^{2}}{J}}
$$




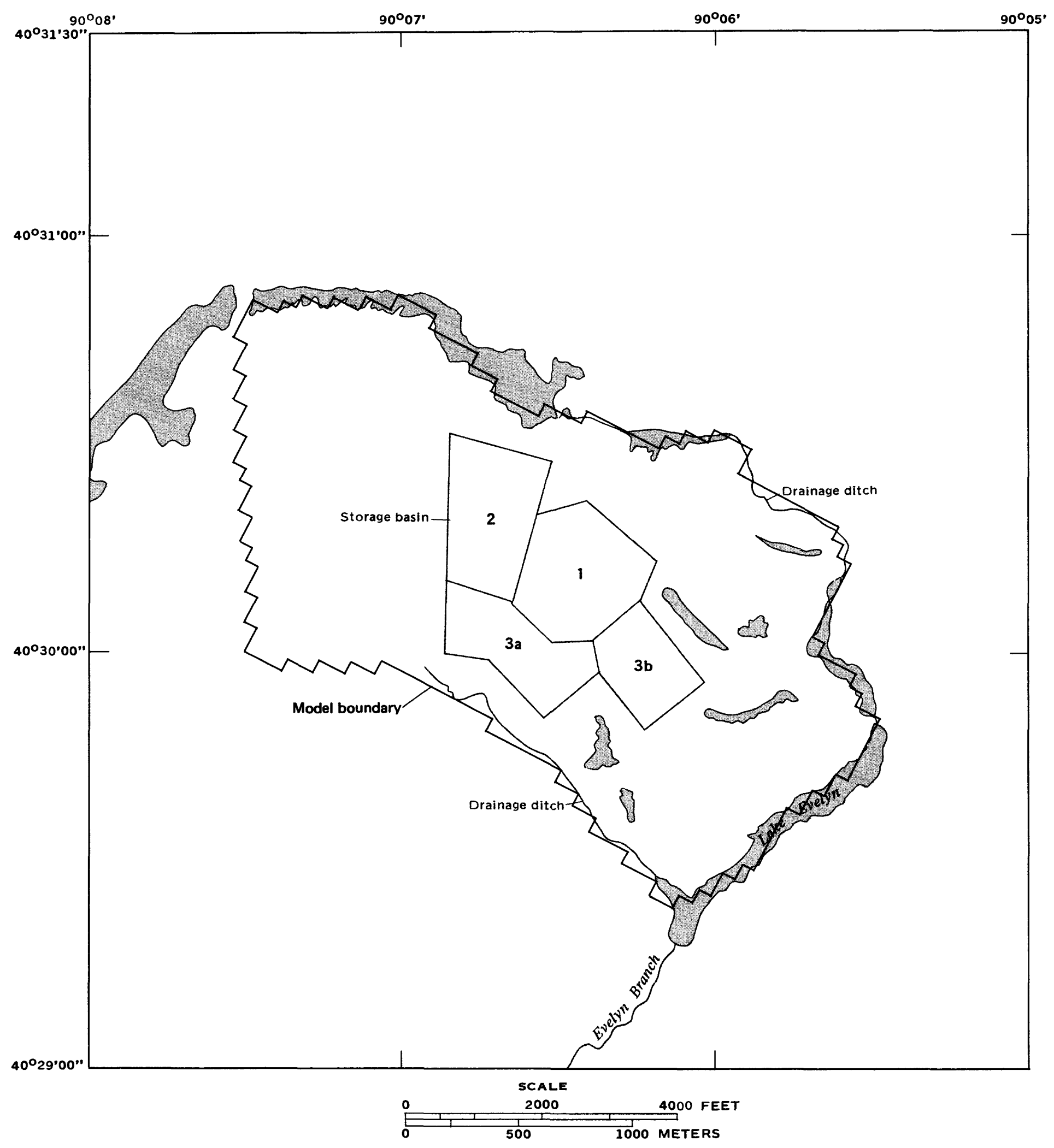

Figure 9. Ground-water-flow model boundaries. 
and

$E$ is a measure of the overall difference between observed and computed heads,

$h_{i}$ was the observed head at node $i$,

$\mathbf{h}_{\mathbf{i}}$ was the computed head at node $\mathrm{i}$,

$\mathrm{J}$ was the number of nodes where heads were measured $(\mathrm{J}=17)$.

\section{Results}

The best match of simulated water levels with pre-basin water levels was achieved by using an areal recharge value of $4.0 \times 10^{-9} \mathrm{ft} / \mathrm{s}(1.51 \mathrm{in} / \mathrm{yr})$. Although few data are available for comparison, Schicht and Walton (1961) determined a recharge rate of $3.89 \mathrm{in} / \mathrm{yr}$ in the Hadley Creek basin, also in west-central Illinois. Considering the high clay content and sloped topography of the storage basin area, the model value of $1.51 \mathrm{in} / \mathrm{yr}$ is reasonable. The pre-basin water-table contour map constructed from computed head values (fig. 10 ) is similar to the map (fig. 5) constructed from observed data.

When increased values of recharge were assigned to all nodes representing basins, the computed result was a large water-level mound in the basin area. However, the water levels were unrealistically high, and the mound was much broader than that indicated by observed data. Because basin 1 is the only basin having its bottom constructed below the water table and because saturated permeabilities are generally much higher than unsaturated permeabilities within the same material, it was thought that basin 1 was most likely the major source of leakage from the basins. Therefore, several simulations were made with various recharge rates for nodes representing basin 1 , while allowing no recharge for nodes representing the other three basins. The best fit with the observed head values from June 1979 (fig. 11) was achieved by adjusting the recharge from nodes representing basin 1 to $5.6 \times 10^{-8} \mathrm{ft} / \mathrm{s}$ (21.2 in/yr) and by using an areal recharge rate of $4.0 \times 10^{-9} \mathrm{ft} / \mathrm{s}(1.51 \mathrm{in} / \mathrm{yr})$. The error function value associated with these parameter values is 2.99 feet. The similarity between maps drawn from computed values and observed data is shown by comparing figures 11 and 6 . Details of some of the more extreme contour variations shown in figure 6 are not reflected by the model output in figure 11 because of the use of averaged parameter values.
The total rate of water leaking from the storage basins can be calculated by

$$
\mathrm{V}=\mathrm{q}_{\mathrm{reb}}\left(\mathbf{A}_{\mathrm{J}}\right)\left(\mathrm{J}_{\mathrm{reb}}\right),
$$

where

$\mathrm{V}$ is the rate of leakage from the basins $\left(\mathrm{L}^{3} / \mathrm{T}\right)$,

$\mathrm{q}_{\text {reb }}$ is the recharge rate at each node representing leakage $(\mathrm{L} / \mathrm{T})$,

$A_{J}$ is the area of each node $\left(L^{2}\right)$,

$\mathrm{J}_{\text {reb }}$ is the number of nodes where leakage occurs (dimensionless);

thus by substitution,

$\mathrm{V}=5.6 \times 10^{-8} \mathrm{ft} / \mathrm{s}\left(200 \mathrm{ft}^{2}\right)(35)=0.0784 \mathrm{ft}^{3} / \mathrm{s}$ or about 91,600 yards per year.

The annual leakage represents 4.5 percent of the 2 million cubic yard capacity of basin 1 .

The hydraulic conductivity, thus, the effectiveness of the clay liner beneath basin 1, can be calculated by

$$
\mathrm{q}_{\text {rebl }}=\frac{\mathrm{K}^{\prime}}{\mathrm{M}}\left(\mathrm{g}_{\mathbf{i}}-\mathrm{g}_{\mathbf{i}}\right)
$$

where

$\mathrm{q}_{\mathrm{reb} 1}$ is the recharge rate from basin 1 , $(\mathrm{L} / \mathrm{T})$,

$\mathrm{K}^{\prime}$ is the hydraulic conductivity of the clay liner

$\mathrm{M}$ is the thickness of the clay liner $(\mathrm{L})$

$\mathrm{g}_{\mathrm{i}}$ is the liquid-level altitude at each node representing basin $1(\mathrm{~L})$,

$\mathbf{g}_{\mathbf{i}}$ is the average computed head value of the water table at nodes representing basin $1(\mathrm{~L})$.

Using a constant liquid-level altitude of 669 feet for basin 1 (fig. 7), an average computed head value of 661 feet for nodes representing basin 1, a clayliner thickness of 2 feet, and the model-derived recharge rate for basin 1 of $5.6 \times 10^{-8} \mathrm{ft} / \mathrm{s}$, equation 5 yields: 


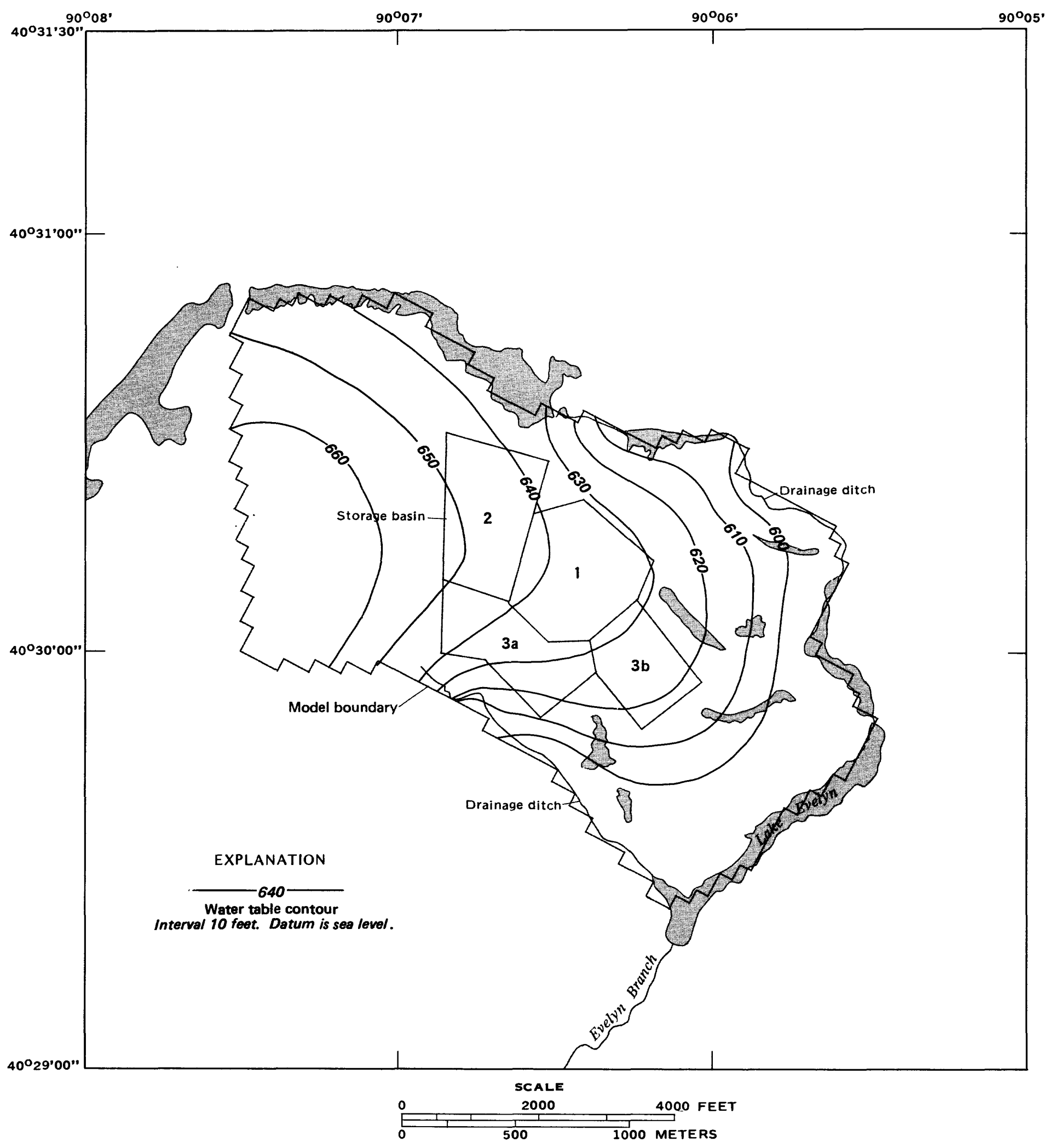

Figure 10. Water table before construction, based on model-computed data. 


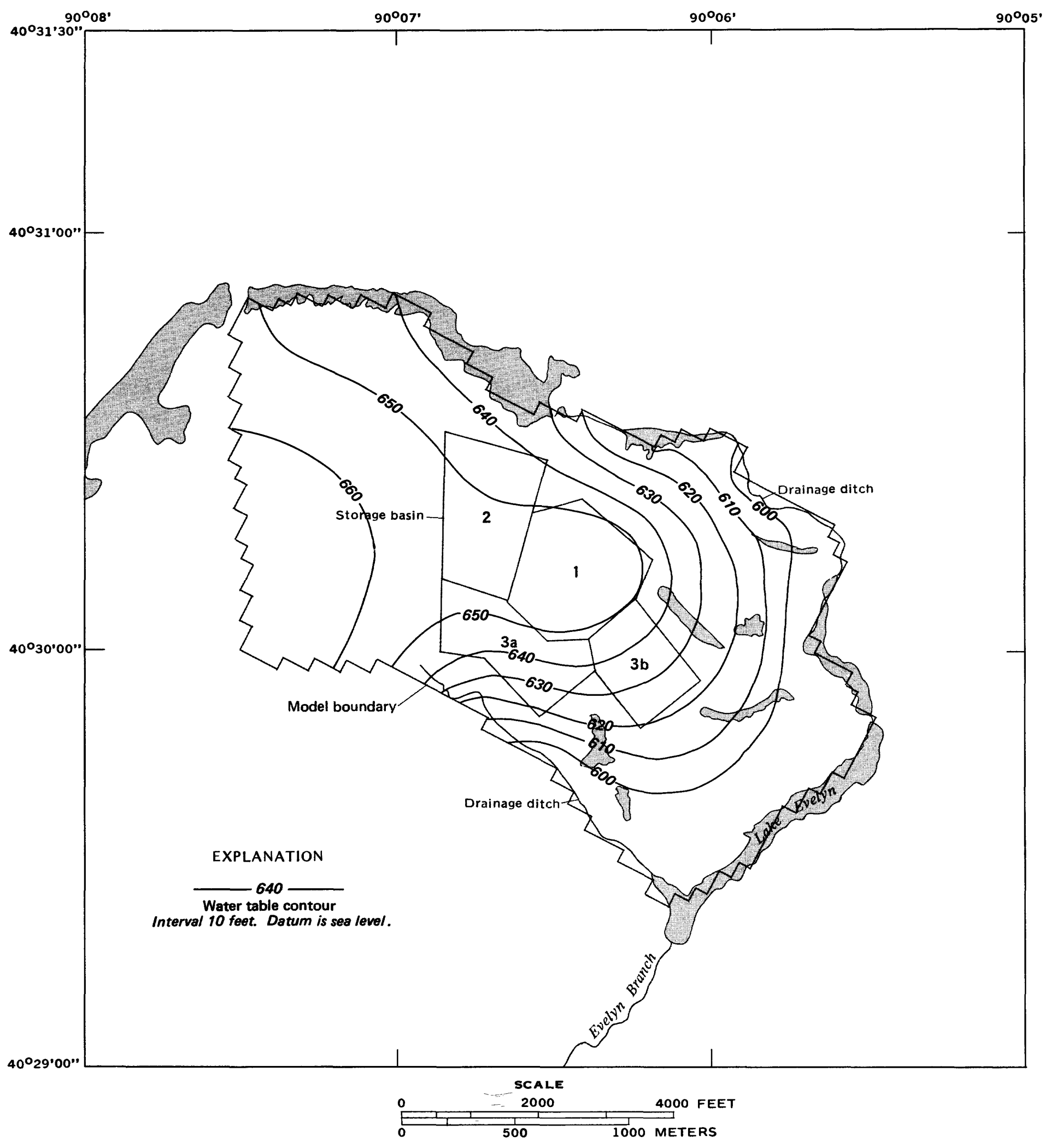

Figure 11. Water table, June 1979, based on model-computed data. 
which is 0.002 times the hydraulic conductivity used for the mine spoil.

The linear ground-water flow velocity was calculated by the equation

$$
\mathrm{V}=\frac{-\mathrm{K} d \mathrm{H}}{\mathrm{P} \mathrm{dL}}
$$

where

$\mathrm{V}$ is the average seepage velocity $(\mathrm{L} / \mathrm{T})$,

$\mathrm{dH} / \mathrm{dL}$ is the head gradient between nodes (dimensionless),

$\mathrm{K}$ is the hydraulic conductivity of the mine spoil $(\mathrm{L} / \mathrm{T})$,

$P$ is the effective porosity of the mine spoil (dimensionless).

Using a porosity value of 20 percent and the hyraulic conductivity and calculated head gradients between nodes from the best fit simulation, the average velocity at nodes representing basin 1 is 23 feet per year. The average velocity at nodes representing all four basins is 21 feet per year. Because the gradient decreases with distance from the basins, the flow velocity also decreases with distance from the basins. Therefore, the values of 23 and 21 feet per year represent maximum estimates of average velocities in the modeled area.

\section{Sensitivity and Reliability}

The boundary conditions were altered in several ways to test their effect on computed heads. The western boundary was changed to a constant-head boundary and the head altitude was varied by amounts representative of changes in observed values. These changes produced little or no differences in the computed heads near the storage basins. The constant head boundaries to the north, east, and south were similarly tested by altering head values. These alterations changed the computed heads near the basins on the order of 0.2 feet, which, for this particular model, is insignificant.

Sensitivity analyses were done by changing values for hydraulic conductivity of the mine spoil, areal recharge, and leakage from basin 1 . The value of each parameter was increased, in turn, by 100 percent, then decreased, in turn, by 50 percent, while holding the other two parameters constant at their best-fit values. The computed heads were then compared to those of the best fit model and to the observed heads by calculating the respective error functions. The results (table 4) indicate that the model is highly sensitive to changes in all three parameters. Changes in hydraulic conductivity values for mine spoil have the greatest effect, followed by changes in leakage values for basin 1 . Changes in areal recharge values affect the model the least. Note that the model is not unique in that the same error function value could probably be obtained by varying any two of the three parameters. For example, increasing the hydraulic conductivity 100 percent and decreasing the areal recharge 50 percent produce the same average head change and error function values (table 4).

Model sensitivity to aquifer thickness was not analyzed. However, the results would be the same as those for hydraulic conductivity because in the calculations (Eq. 2) they are combined as transmissivity, which is the hydraulic conductivity multiplied by the aquifer thickness.

To test further the effect of averaging the hydraulic conductivity values, two additional simulations were made by first using the mean hydraulic conductivity value plus one standard deviation of the observed values (table 3 ) and then by using the mean value minus one standard deviation. Areal recharge and leakage from basin 1 were then adjusted until the two sets of output exactly matched those from the best fit model. The results show that if hydraulic conductivity is increased 82 percent (one standard deviation), recharge and leakage must also be increased 82 percent to produce the same model output. Similarly, if hydraulic conductivity is decreased 82 percent, then recharge and leakage must also be decreased 82 percent. If more accurate hydraulic conductivity data were to become available, it would be a simple matter, as indicated above, to compute new recharge values to represent the system.

Use of the model to predict response to a particular stress would need to be done with caution for the following reasons:

(1) The assumption that the system was at steady state in June 1979 may not be entirely accurate. There are no 1971-78 data on water levels near the basins; therefore, whether the water table is still adjusting to recharge from the basins is unknown. Over the period of record, there were no increasing 
Table 4. Results of sensitivity analyses of major parameters used in the ground-water flow model.

Parameter

Alteration

100 percent increase

50 percent decrease

100 percent increase

50 percent decrease

100 percent increase

50 percent decrease
Average head

change

(feet)

13.44

21.82

6.74

13.44

16.0

9.49
Range of head change (feet)

$4 \cdot 3-18$

14.98

$22 \cdot 16$

$8-28 \cdot 2$

6.69

14.98

$4 \cdot 3-18$

17.01

$4.4-23.9$

11.19

K - hydraulic conductivity of the mine spoil aquifer

$R$ - areal recharge

$R^{\prime}$ - recharge rate from basin 1

trends in water levels, but this period was too short to be conclusive.

(2) Variations in precipitation, such as particularly wet or dry years, would alter areal recharge and change the relation between the water table and the basins.

(3) It is possible that basin 1 is not the only basin that is leaking. If this were the case, however, the volumetric rate of leakage for all the basins would not be substantially different from that computed for basin 1. Further rise in water-table altitude produced by recharge from basin 1 or increased areal recharge could saturate the materials underlying the other three basins, thus increasing the potential for leakage from these basins.

(4) Further rise in water-table altitude, together with lowering the liquid level in basin 1 , could result in a condition where the hydrostatic pressure outside the clay liner would be greater than that inside. This pressure could damage the clay liner and increase leakage if the basin were refilled.
(5) Emptying the basins and allowing the clay liner to dry and crack could result in increased leakage if the basins were refilled.

Response of the hydrologic system near the basins to the above situations can be determined only through continued monitoring of the water table near the basins and by refinement of the model.

\section{CHEMICAL COMPOSITION OF SLUDGE AND SUPERNATANT}

Mean values and ranges of concentration for the principal chemical constituents and physical properties of sludge (table 5) show that although the range is large for many constituents, the yearly means for 1978 and 1979 are essentially the same. Concentrations of many constituents were several times greater than those commonly found in waters in Illinois. The major constituents were ammonia, organic nitrogen, iron, phosphorus, calcium, aluminum, and magnesium. Alkalinity and specific con- 

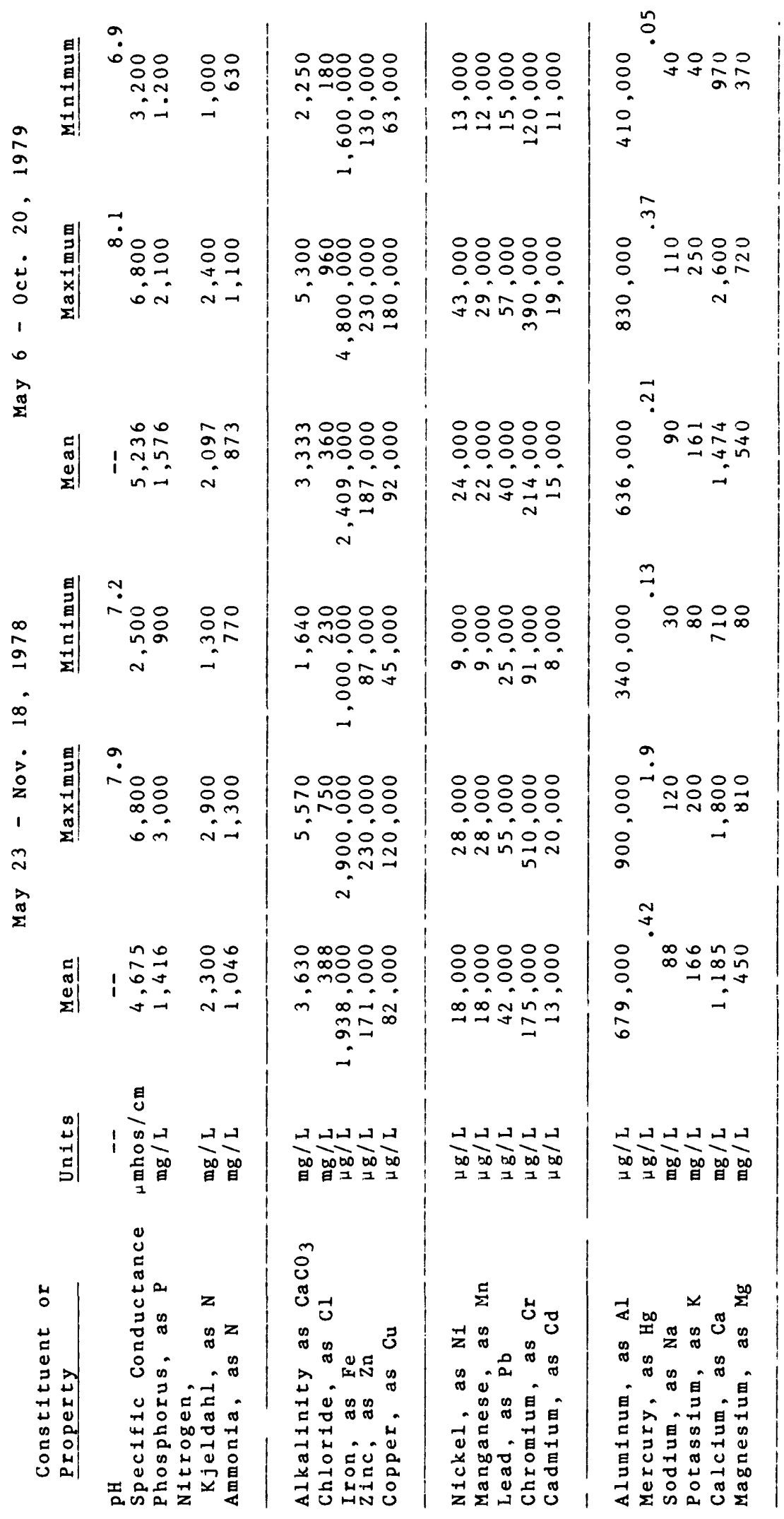

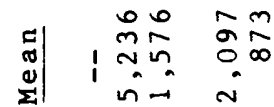

m

莡

$$
\text { घ) ñ }
$$

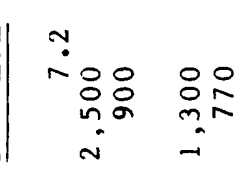

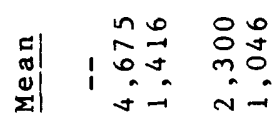

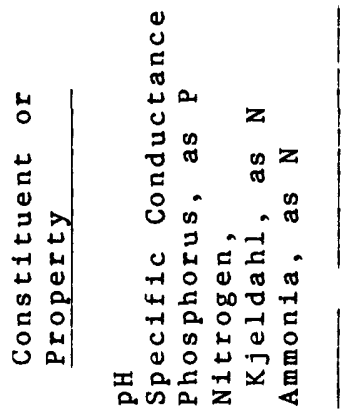

!a 
ductance were both high, about $3,600 \mathrm{mg} / \mathrm{L}$ as $\mathrm{CaCO}_{3}$, and about $4,700 \mu \mathrm{mho}$, respectively. Minor consitiuents, such as cadmium and chromium, commonly found in concentrations less than 100 $\mu \mathrm{g} / \mathrm{L}$ in waters, had mean concentrations in the range of 13,000 to $214,000 \mu \mathrm{g} / \mathrm{L}$.

Samples collected in June 1979, from sludge basin 1 and supernatant basin $3 a$, were centrifuged to remove the solids to obtain samples representative of the liquid that could potentially travel from the basins into the ground water system. Results of analyses of the liquid remaining after centrifuging (table 6) show significant decreases, with respect to raw sludge, in concentrations of most constituents. These decreases indicate that a large fraction of the constituents in the sludge were sorbed to or otherwise associated with solids. Notable differences were observed in alkalinity, ammonia, organic nitrogen, calcium, magnesium, phosphorus, and the minor elements. With the exception of alkalinity and, in part, ammonia, the differences can probably be attributed to sorption on the removed solid organic materials centrifuged out. The high alkalinity in the raw and centrifuged sludge can probably be partly attributed to organic compounds in the sludge, which interfere with the titration for alkalinity. Some of these compounds are removed by centrifuging; some are removed by degradation in the supernatant basin. The high alkalinity remaining in the centrifuged sludge may be either from bicarbonate or from interferences with the alkalinity determination caused by dissolved organic compounds. The decreases in ammonia and organic nitrogen probably result from volatilization of ammonia and decreases in organic matter high in concentration of nitrogen.

The principal constituents remaining in the fluid part of the sludge and supernatant after centrifuging are ammonia, chloride, and phosphorus. In addition, alkalinity represents a significant anionic component of both waters.

\section{GROUND-WATER QUALITY}

The predominant factor affecting the groundwater quality is surface mining. The acids formed by oxidation of ferrous sulfide minerals (pyrite, marcasite) are neutralized when hydrogen ions react with calcium or magnesium carbonate. These reactions result in high calcium, magnesium, bicarbonate, and sulfate concentrations, all of which are present in the mined areas of the project site. Water types range from calcium bicarbonate in unmined areas to magnesium and calcium sulfate in mined areas (Patterson and others, 1982).

Samples from 24 wells (fig. 2) were used to determine the chemical characteristics of the ground water. Six MSDGC wells, in the mine spoil away from the storage basins, were used to determine background chemical concentrations. These wells, with the exception of W13 which was sampled with a copper bailer, were pumped with permanently installed submersible pumps until the water became clear; then the sample was taken. Water samples from 18 wells immediately adjacent to the basins were used to determine chemical concentrations near the basins. These wells were pumped dry with a portable submersible pump, allowed to recover, and then sampled with a stainless steel bailer. All water samples were analyzed by the MSDGC laboratory in Chicago.

Mean chemical concentrations in samples from the six wells away from the basins are listed in table 7 , and concentrations of principal cations and anions are listed in table 8. Magnesium is the principal cation in wells W9, W12, W13, and W18. Magnesium and calcium are present in essentially equivalent concentrations in W14, and magnesium, calcium, and sodium are essentially equivalent in W15.

Sulfate constitutes over 60 percent of the anions in water samples from all six wells. Bicarbonate (calculated from alkalinity) is the second most abundant anion, and chloride constitutes less than 5 percent of the anions.

Mean chemical concentrations in samples from the 18 wells near the storage basins are listed in table 9, and concentrations of principal cations and anions are listed in table 10. Sodium is the principal cation in water from 12 of the 18 wells with percentages ranging from 47 in well 913 to 77 in well 906 . Sodium and magnesium are present in equivalent concentrations in well water from 914; magnesium is the principal cation in wells $901,902,903$, and 915; and calcium predominates in water from well 910. 
Table 6. Chemical analyses of centifuged sludge and supernatant.

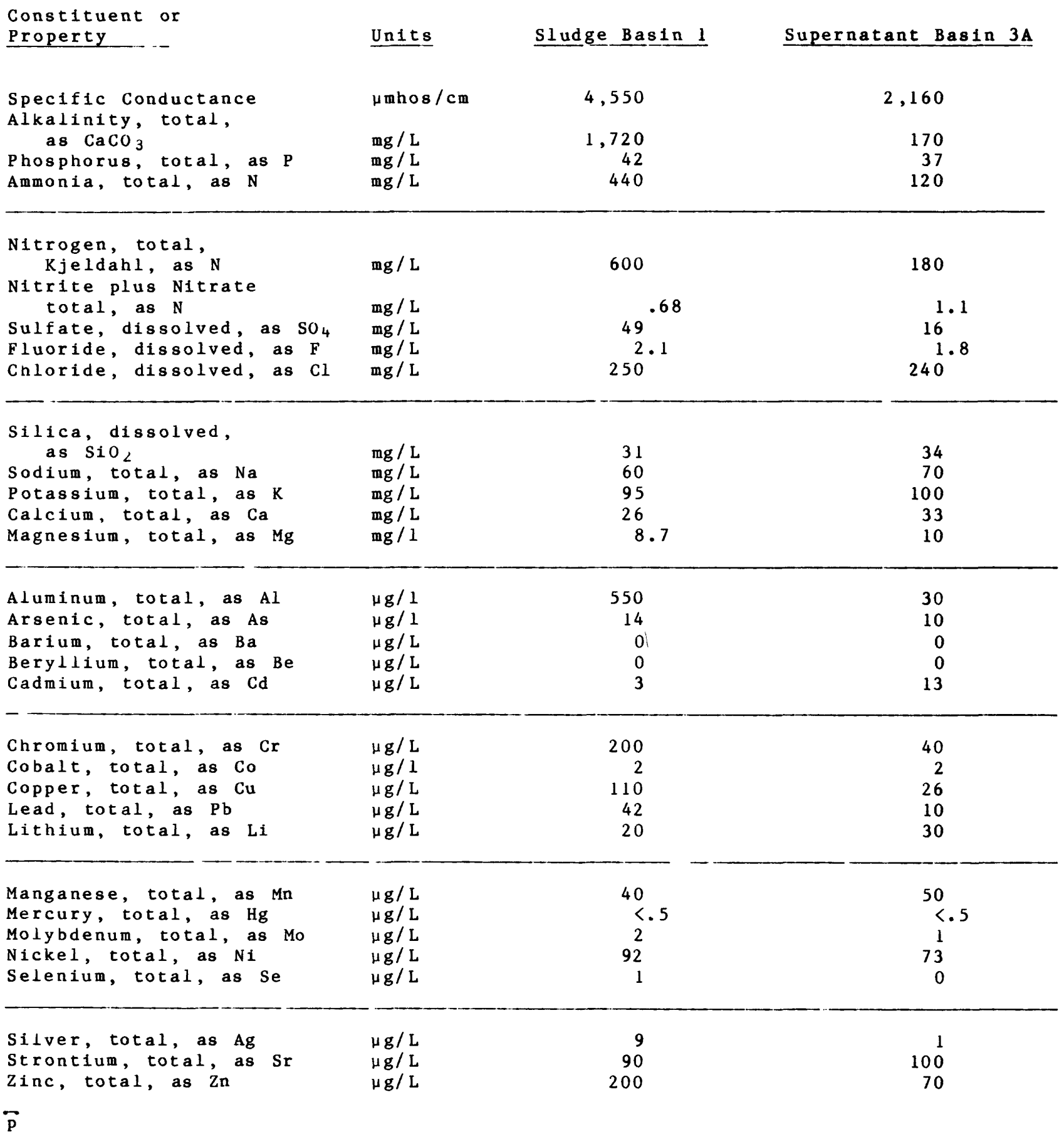


Table 7. Summary of chemical analyses of settled, unfiltered water samples

from wells away from the storage basins, (arithmetic means for 7 samples per well).

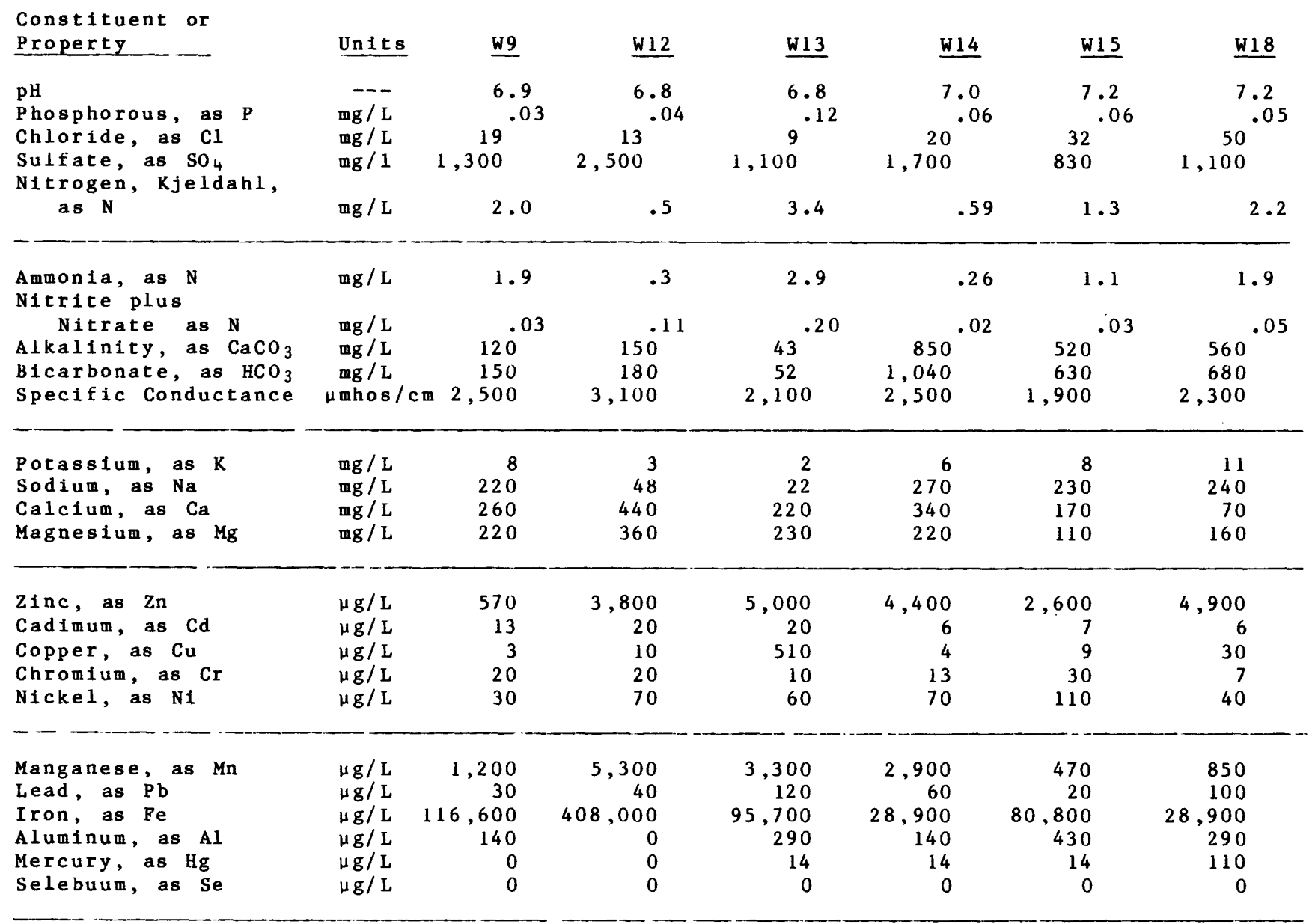

Table 8. Concentration, in milliequivalents per liter, and percent reacting values of the principal cations and anions in settled, unfiltered samples from wells away from the storage basins.

\begin{tabular}{|c|c|c|c|c|c|c|}
\hline \multirow[b]{2}{*}{$\begin{array}{l}\text { We } 11 \\
\text { No. }\end{array}$} & \multicolumn{6}{|c|}{ Anions } \\
\hline & $-\underline{\mathrm{SO}}_{4}$ & $\begin{array}{l}\left(\begin{array}{l}\text { Per } \\
\text { cent }\end{array}\right. \\
\end{array}$ & $\mathrm{HCO}_{3}$ & $\begin{array}{c}(\text { Per }- \\
\text { cent })\end{array}$ & C1 & $\begin{array}{c}\left(\begin{array}{l}\text { Per } \\
\text { cent }\end{array}\right) \\
\end{array}$ \\
\hline W9 & 27.1 & $(90)$ & 2.5 & (8) & 0.5 & (2) \\
\hline W1 2 & 51.9 & (94) & 3.0 & (5) & 0.4 & (1) \\
\hline W13 & 35.4 & $(97)$ & 0.9 & (2) & 0.3 & (1) \\
\hline W14 & 35.4 & $(67)$ & 17.0 & (32) & 0.6 & (1) \\
\hline W1 5 & 17.3 & $(61)$ & 10.3 & $(36)$ & 0.9 & (3) \\
\hline W1 8 & 22.9 & $(65)$ & 11.1 & (31) & 1.4 & (4) \\
\hline
\end{tabular}

\begin{tabular}{|c|c|c|c|c|c|}
\hline & \\
\hline $\mathrm{Ca}$ & $\operatorname{cen} t)$ & $\mathrm{Mg}$ & $\operatorname{cen} t)$ & $\mathrm{Na}$ & (ent) \\
\hline 13.0 & (32) & 18.0 & (44) & 9.6 & (24) \\
\hline 22.0 & (41) & 29.6 & (55) & 2.1 & (4) \\
\hline 11.0 & (36) & 18.9 & (61) & 1.0 & (3) \\
\hline 17.0 & (36) & 18.1 & (39) & 11.7 & (25) \\
\hline 8.5 & (31) & 9.0 & (33) & 10.0 & (36) \\
\hline 3.5 & (13) & 13.2 & (49) & 10.4 & (38) \\
\hline
\end{tabular}


Sulfate is the predominant anion in water from all wells except 904 and 910 , where sulfate and bicarbonate (calculated from alkalinity) concentrations are equivalent. Bicarbonate is the second most abundant anion, and chloride represents 8 percent or less of the total anion concentration in water from each well.

Manganese and iron are the most abundant minor consitutents in water from wells both near and away from the basins. Manganese concentrations range from 470 to $5,300 \mu \mathrm{g} / \mathrm{L}$ away from the basins and from 140 to $4,700 \mu \mathrm{g} / \mathrm{L}$ near the basins. Iron concentrations range from 28,900 to 408,000 $\mu \mathrm{g} / \mathrm{L}$ away from the basins and from 430 to 8,500 $\mu \mathrm{g} / \mathrm{L}$ near the basins. Zinc concentrations range from 570 to $5,000 \mu \mathrm{g} / \mathrm{L}$ away from the basins and from 0 to $350 \mu \mathrm{g} / \mathrm{L}$ near the basins. The higher concentrations of iron and zinc away from the basins probably result from corrosion of old well casings or pump lines.

The only constituents in generally higher concentrations near the basins compared to those away from the basins are sodium, bicarbonate (calculated from alkalinity), and chloride. Sodium concentrations average $172 \mathrm{mg} / \mathrm{L}$ away from the basins and $538 \mathrm{mg} / \mathrm{L}$ near the basins. Bicarbonate and chloride concentrations average 455 and $24 \mathrm{mg} / \mathrm{L}$, respectively, away from the basins and 1,100 and 51 $\mathrm{mg} / \mathrm{L}$, respectively, near the basins. All other constituents except ammonia are essentially equal away from and near the basins. Samples from wells 904 and 914 , near the basins, have anomalously high ammonia concentrations of 63 and $41 \mathrm{mg} / \mathrm{L}$, respectively.

\section{Relation of Ground-Water Quality to Basin Contents}

Higher concentrations of sodium, chloride, bicarbonate, and ammonia in ground water near the basins might suggest movement from the basins to the ground-water system. However, the sodium concentration in ground water near the basins is much higher than the 60 and $70 \mathrm{mg} / \mathrm{L}$ sodium concentrations of the sludge and supernatant samples, which contradicts the possibility of the liquid from the basins being the source of sodium in the ground water. The 250 and $240 \mathrm{mg} / \mathrm{L}$ chloride concentrations in the sludge and supernatant and the $1,720 \mathrm{mg} / \mathrm{L}$ alkalinity (as $\mathrm{CaCO}_{3}$ ) concentration in the sludge are sufficiently high to be the source of the higher chloride and bicarbonate concentrations near the basins. The 440 and $120 \mathrm{mg} / \mathrm{L}$ ammonia concentrations in sludge and supernatant are also sufficiently high to provide the source for the high ammonia concentrations in samples from wells 904 and 914.

The concentrations of chloride, bicarbonate, and ammonia in the sludge and supernatant are sufficiently high to be considered as sources for elevated concentrations near the basins. However, flow velocities generated by the model indicate that, by 1979 , widespread chemical changes in ground water, caused by leakage, were unlikely.

When the basins were constructed, mine spoil was moved from its original location and used as berm and sidewall material. The redisturbance of the mine spoil exposed fresh clay particles and mineral surfaces to weathering, thus increasing the availability of chemicals such as sodium, chloride, and bicarbonate. In addition to leaving minerals more exposed to weathering, the redisturbance made fresh sodium-rich clay surfaces available for release of sodium through cation exchange. The redisturbance could also account for the higher specific conductance near the basins, which averages $3,800 \mu \mathrm{mho}$, as compared with $2,400 \mu \mathrm{mho}$ away from the basins.

\section{SUMMARY AND CONCLUSIONS}

The Metropolitan Sanitary District of Greater Chicago has been operating a sludge-utilization and surface-mine reclamation project in Fulton County, Illinois, since 1971. At the project site, sludge and supernatant are temporarily stored in four basins having a combined storage capacity of 8 million cubic yards.

Ground-water levels for 1969, approximated from surface-mine lake levels, indicate that the water table was above the bottom of storage basin 1 at the time of its construction. A water-table map for June 1979 indicates that the water table in the vicinity of the basins had risen about 10 feet between 1969 and 1979. In 1979, the water table was about 20 feet above the bottom of basin 1 . 
Table 9. Summary of chemical analyses of filtered water samples from wells near the storage basins, (6 samples per well).

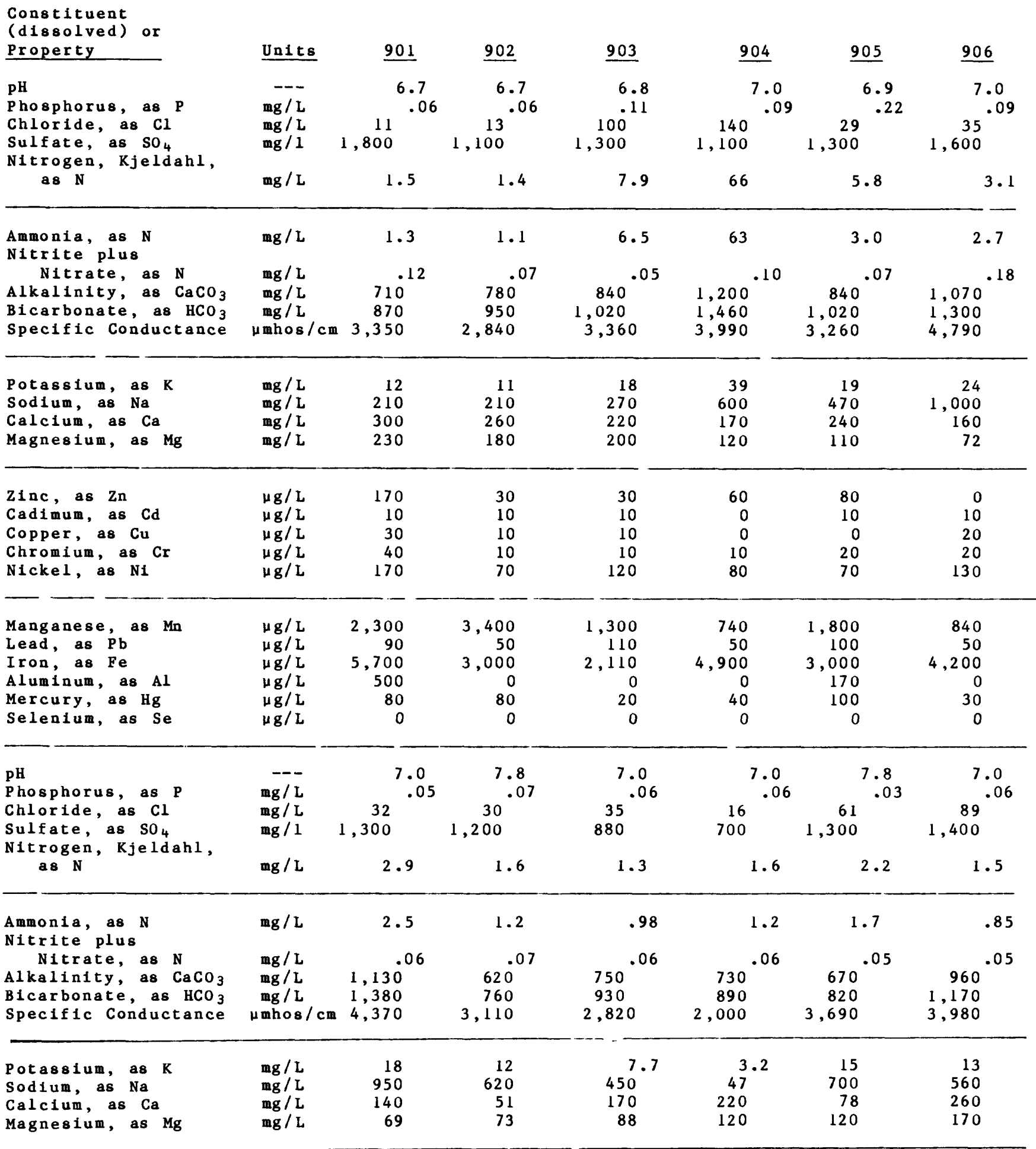


Table 9. Summary of chemical analyses of filtered

water samples from wells near the storage basins (continued).

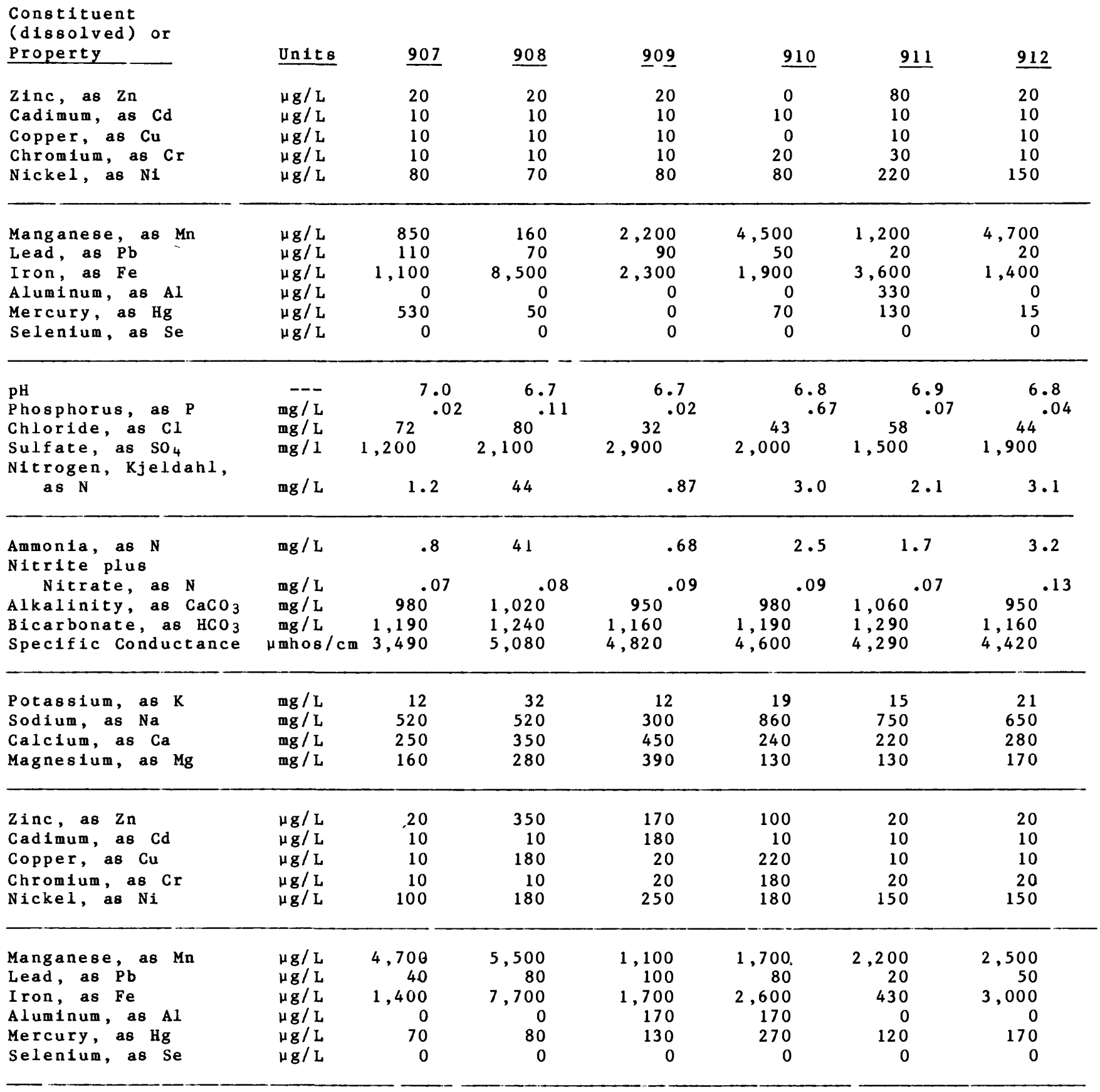




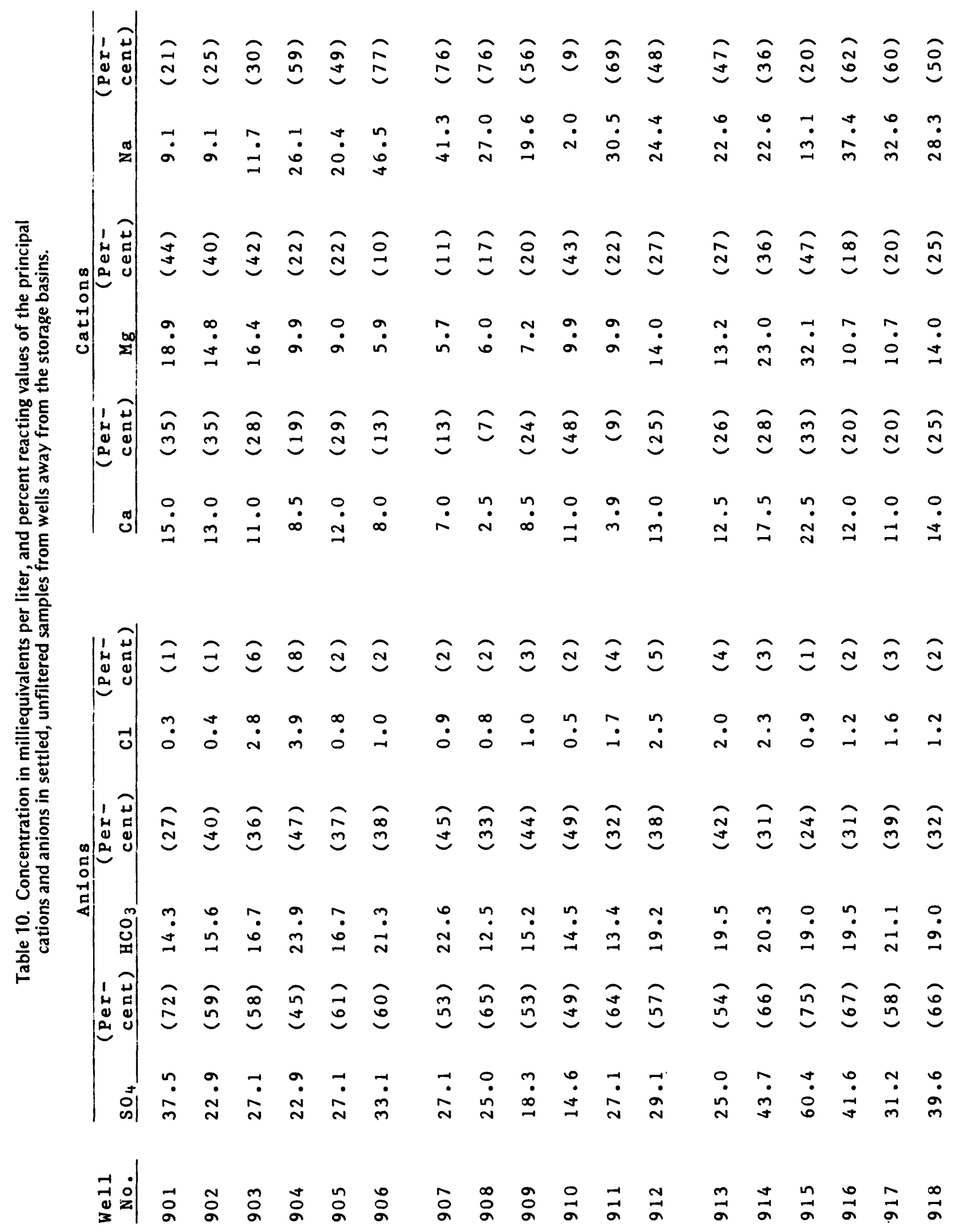


A two-dimensional ground-water flow model indicates that the water-table rise is due to leakage from storage basin 1. Parameter values producing the best fit between computed and observed heads were $7 \times 10^{-6} \mathrm{ft} / \mathrm{s}$ for hydraulic conductivity of the mine spoil, $4 \times 10^{-9} \mathrm{ft} / \mathrm{s}(1.51 \mathrm{in} / \mathrm{yr})$ areal recharge to the ground water system, and $5.6 \times 10^{-8} \mathrm{ft} / \mathrm{s}$ (21.2 in/yr) recharge from storage basin 1. Assuming the system is under steady-state conditions, the rate of water leaking from basin 1 is $91,600 \mathrm{yd}^{3} / \mathrm{yr}$. Using a constant liquid-level altitude of 669 feet for basin 1 , the hydraulic conductivity of the clay liner beneath the basin is calculated to be $1.4 \times 10^{-8} \mathrm{ft} / \mathrm{s}$ or 0.002 times that used for the mine-spoil aquifer. Maximum estimates of the average flow velocities, calculated from gradients derived from the best-fit simulation, are from 21 to $23 \mathrm{ft} / \mathrm{yr}$.

The principal constituents remaining in the sludge and supernatant after the solids are removed are ammonia, chloride, and phosphorus. Alkalinity is a significant anionic component of both sludge and supernatant. The principal cation in ground water away from the storage basins is magnesium, and the principal anion is sulfate. Near the storage basins the principal cation is sodium, and the principal anion is sulfate. The only constituents found in generally higher concentrations near the basins, compared with those away from the basins are sodium, chloride, and bicarbonate.

Although concentrations of chloride and alkalinity in the sludge and supernatant are sufficiently high to be possible sources for the higher concentrations of chloride and bicarbonate in the ground water, the concentration of sodium is higher in the ground water than in the sludge and supernatant. In addition, the flow velocities, calculated from the model, on the order of 21 to $23 \mathrm{ft} / \mathrm{yr}$, indicate that few if any of the wells are near enough to the source to have as yet been affected by chemicals leaking from the basins.

When the basins were constructed, mine spoil was moved from its original location and used as berm and sidewall material. This redisturbance of the mine spoil exposed fresh clay particles and mineral surfaces to weathering, thus increasing the opportunity for dissolution of chemicals such as sodium, chloride, and bicarbonate. This could also cause higher sodium concentrations by making fresh, sodium-rich clay surfaces available for release of sodium through cation exchange. 


\section{REFERENCES}

Bouwer, Herman, and Rice, R. C., 1976, A slug test for determining hydraulic conductivity of unconfined aquifers with completely or partially penetrating wells: Water Resources Research, v. 12 , no 3 , p. $423-428$.

Bredehoeft, J. D., and Pinder, G. F., 1970, Digital analyses of areal flow in multiaquifer groundwater systems: A quasi three-dimensional model: Water Resources Research, v. 6, no. 3, p. 883-888.

Patterson, G. L., Fuentes, R. F., and Toler, L. G., 1982, Hydrologic characteristics of strip-mined land reclaimed by sludge irrigation: U.S. Geo- logical Survey Water-Resources Investigations $82-16,34 \mathrm{p}$.

Schicht, R. J., and Walton, W. C., 1961, Hydrologic budgets for three small watersheds in Illinois: Illinois State Water Survey Report of Investigation $40,40 \mathrm{p}$.

Trescott, P. C., Pinder, G. F., and Larson, S. P., 1976, Finite-difference model for aquifer simulation in two dimensions with results of numerical experiments: U.S. Geological Survey Techniques of Water-Resources Investigations, book 7, chapter $\mathrm{C} 1,116 \mathrm{p}$. 